\title{
Jens Glad Balchen: A Norwegian Pioneer in Engineering Cybernetics
}

\author{
Morten Breivik ${ }^{1}$ Gunnar Sand ${ }^{2}$ \\ ${ }^{1}$ Centre for Ships and Ocean Structures, Norwegian University of Science and Technology, NO-7491 Trondheim, \\ Norway. E-mail: morten.breivik@ieee.org \\ ${ }^{2}$ The University Centre in Svalbard, NO-9171 Longyearbyen, Norway. E-mail: gunnar.sand@unis.no
}

\begin{abstract}
This paper tells the story of Jens Glad Balchen (1926-2009), a Norwegian research scientist and engineer who is widely regarded as the father of Engineering Cybernetics in Norway. In 1954, he founded what would later become the Department of Automatic Control at the Norwegian Institute of Technology in Trondheim. This name was changed to the Department of Engineering Cybernetics in 1972 to reflect the broader efforts being made, not only within the purely technical disciplines, but also within biology, oceanography and medicine. Balchen established an advanced research community in cybernetics in postwar Norway, whose applications span everything from the process industry and positioning of ships to control of fish and lobster farming. He was a chief among the tribe of Norwegian cybernetics engineers and made a strong impact on his colleagues worldwide. He planted the seeds of a whole generation of Norwegian industrial companies through his efforts of seeking applications for every scientific breakthrough. His strength and his wisdom in combination with his remarkable stubbornness gave extraordinary results.
\end{abstract}

Keywords: Jens Glad Balchen, Servo Engineering, Automatic Control, Engineering Cybernetics, IFAC, NFA, DIANA, Ship Automation, DP, Cyberfish, Lobster Farming, Golden Feedback Loop

\section{Introduction}

The son of an electrical engineer, Jens Glad Balchen was born in Kristiansand on the southern tip of Norway on the 20th of April 1926. He lived to be almost 83 years old, and passed away on the 12th of April 2009 in Trondheim, a city where he had spent most of his life teaching, researching and preaching the gospel of Engineering Cybernetics.

In this 30th anniversary edition of the journal originally founded by Balchen in 1980, we attempt to give a glimpse into the life and career of this great Norwegian cyberneticist. The following account is by no means complete, and we recommend consulting other sources for additional details. In particular, this work originates from a chapter on Balchen appearing in (Sand and Dragland, 2002). It is our hope that the following story can contribute to spreading the word about Jens' adventures and give inspiration to new generations of control engineers around the world.

\section{Free the Slaves}

"No humans should perform slave work. ... It is not interesting, it is tiring and the payment is low. ... All work that can be classified as unworthy for humans should be automated."

This citation is taken from an interview appearing in the Norwegian newspaper Aftenposten on the 8th of January 1966. The interview is accompanied by a large picture of an eager-looking man with watchful, friendly eyes and short, keen hair wisps pointing straight up in the air. Jens Glad Balchen, an almost 40-year 


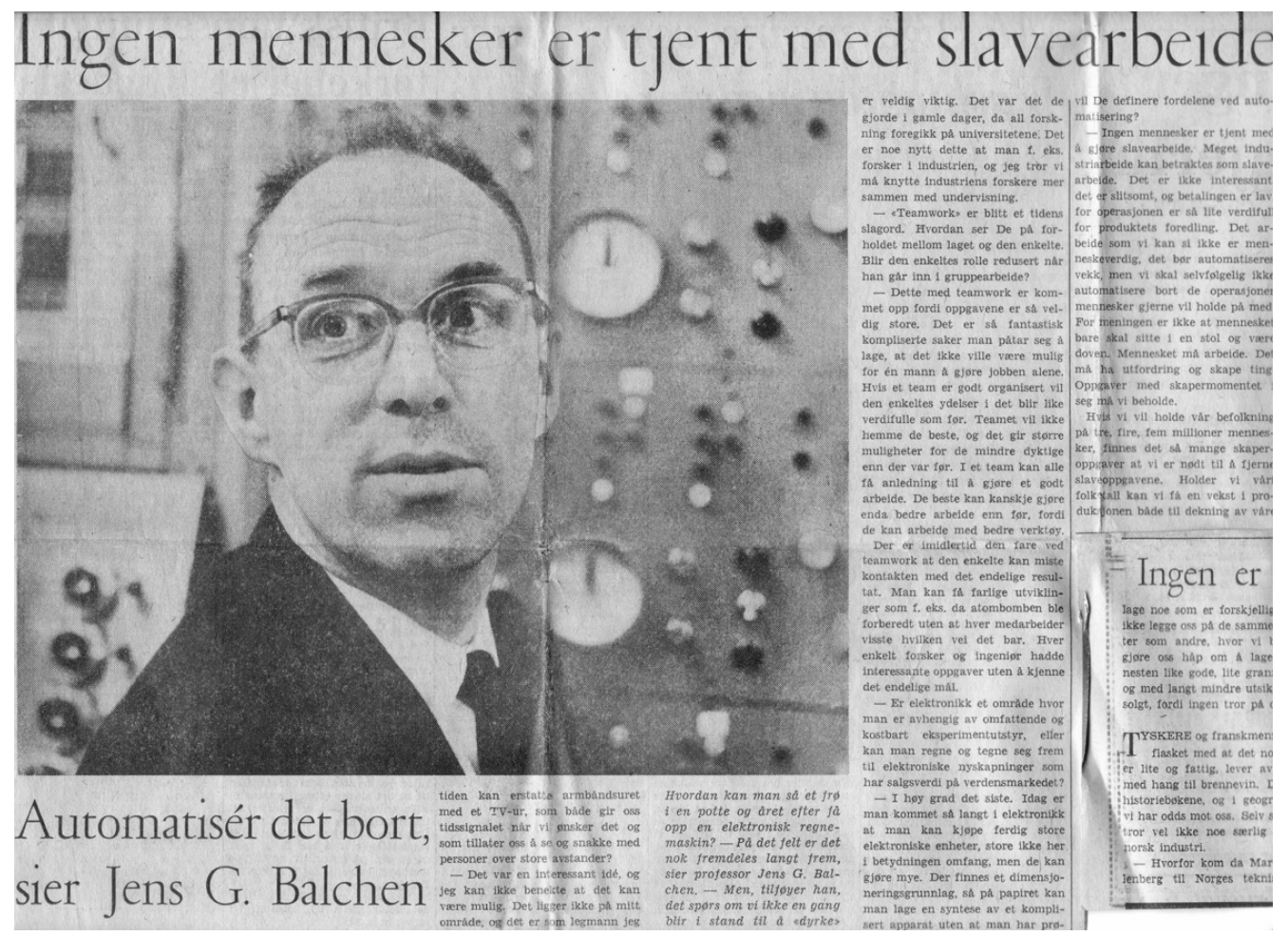

Figure 1: A young and ambitious professor Balchen thinks humans are unfit for slave labor: "Automate it away!"

old professor at the Norwegian Institute of Technology (Norges tekniske høgskole, NTH), is photographed in front of a wall full of gauges and switches. The Aftenposten journalist characterizes Jens as one of the most colorful personalities at NTH and describes his Department of Automatic Control as ". . an anthill of future-minded collaborators and inspired students."

Jens found the slaves that should be set free in the process industry. It started with Elkem in Mosjøen and continued at Sunndalsøra: "There were a lot of people there. They didn't know chemistry or thermodynamics. They had an unconscious relationship with temperature and wasted energy. I thought it should be possible to control the processes better, preferably making them run by themselves. Read instruments and feed aluminum oxide automatically. Enabling all these people to do something meaningful elsewhere."

In Aftenposten, Jens spoke about Norwegian industry products: "We must get our industry to pursue highly refined products ... and we must make something that is different. We shouldn't manufacture the same products as everyone else, where we can only hope to make them almost as good and a bit more expensive." As an example, he suggested that while others made cars with four wheels and a steering wheel, we could make cars with three wheels mounted on the roof.
Then adding: "If someone finds that useful."

Through the interview, Aftenposten made its readers aware of a rising star in academia. Jens Glad Balchen administered new knowledge with great importance for the postwar society. In due time, he was to revolutionize parts of Norwegian industry and commerce. The list of products and companies would be quite lengthy from this man who also left behind an impressive academic production.

\section{Early Years}

As already mentioned, Jens was born in Kristiansand on the south coast of Norway. His father, also named Jens Glad Balchen, originally came from the city of Bergen where he got his education as an electrical engineer. Jens Sr. came to Kristiansand during the First World War and met his wife Ingeborg there. He later became a representative for Siemens in Southern Norway, which meant that Jens Jr. grew up with all kinds of new electrical appliances, including refrigerators, washing machines, centrifuges, etc., everything of the Siemens brand (Asphjell and Børresen, 2004).

Jens remembers a very good upbringing, with summers at Hamresanden beach. No wonder he acquires 


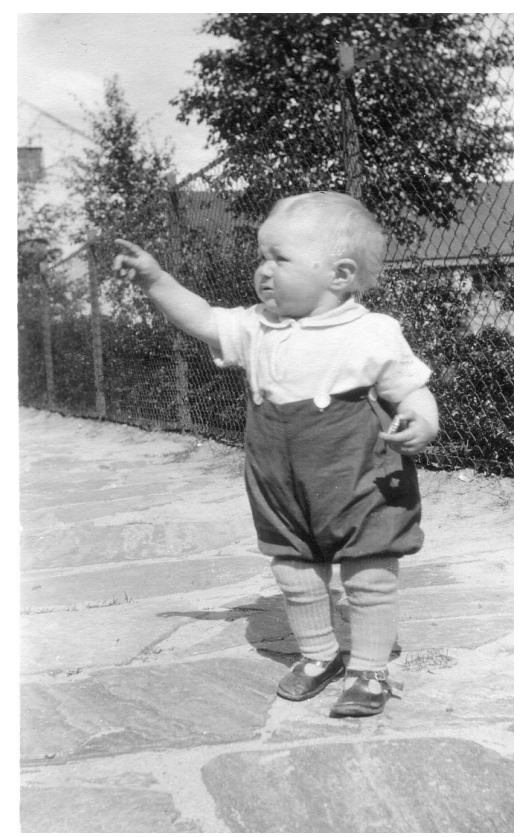

Figure 2: One-year old Jens Glad Balchen enjoying the Norwegian National Day on May 17th, 1927.

a lifelong fascination for the ocean and its mysteries. Jens is also an eager boy scout and has a talent for drawing. Even though he attends the art academy in Kristiansand from the age of twelve, there is no doubt he is going to be an electrical engineer. After graduating from high school in 1944, followed by a short stint at Siemens in Oslo, Jens heads toward Trondheim in the autumn of 1945 to become a student at a worn-out NTH. Here, the story of his cybernetic career starts.

\section{A Student in Postwar Norway}

Norway is face down as a consequence of the war. The nation hasn't followed the technological development and the rebuilding has barely started. Only a few competent industrial companies exist, but they typically lack both capital and technology.

However, some actions are soon taken: In 1946, the government establishes the Royal Norwegian Council for Scientific and Industrial Research (Norges teknisknaturvitenskapelige forskningsråd, NTNF), which again establishes the Central Institute for Industrial Research (Sentralinstitutt for industriell forskning, SI) in Oslo (Buland, 1995). NTNF is an independent agency tasked with promoting research for the benefit of Norwegian industry and society, both initiating and coordinating publicly funded research programs carried out by applied research institutes, universities and by the industry itself.

In the same period, the Norwegian Defence Research Establishment (Forsvarets forskningsinstitutt, FFI) and the Institute for Atomic Energy (Institutt for atomenergi, IFA) are established. FFI and IFA are centers focusing on applied military and civilian research. Money is made available to build national competency in areas that are considered important for the country. Nuclear energy and electronics are among the first priority areas. Automation is soon to follow.

In Trondheim, the professors at NTH join forces with the local municipality and industries to found the research organization SINTEF in 1950 (Gulowsen, 2000). This organization, today the largest in Scandinavia, is formed to encourage industrially-oriented technology research at NTH. In its early years, SINTEF was often characterized as NTH's 'sales office'.

During the spring of 1950, Jens Glad Balchen graduates in electrical engineering from NTH with the thesis Static and Dynamic Stability in Electrical Power Grids. He earns the protected Norwegian degree of "sivilingeniør", considered by NTH to be equivalent to a MSc degree.

Working on his thesis in the autumn of 1949, 23-year old Jens discovers the book Principles of Servomechanisms (Brown and Campbell, 1948) which will become a great inspiration: "It was the reason I got started with control engineering. It changed my life so to speak." (Asphjell, 2004). The book explains how the elements in a complex system mutually affect each other, and how systems and processes can be controlled to reach desired goals without mistakes and negative effects. According to the authors Brown and Campbell, such functionality can be achieved by measuring the output of a system and making adjustments to the input based on this measurement.

In the paper industry for example, timber passes through processes like chopping, addition of chemicals and stirring, while influence factors such as pressure, water and speed are employed. A small change in the pressure can have great effects. But with the proper measurement equipment, the book says, these factors can all be affected without over- or underfeeding. Thus, the relationship between the components and their mutual influence must be figured out.

What Jens realizes while reading is that these concepts can become important for Norway and Norwegian industry. But to get others to understand the same thing, he needs knowledge. And to get knowledge, he needs to go to the United States. He applies for a scholarship, which he wins in competition with a school mate who has a 1/100th poorer GPA.

Servo engineering was first developed as a discipline by the Americans during the Second World War. In 


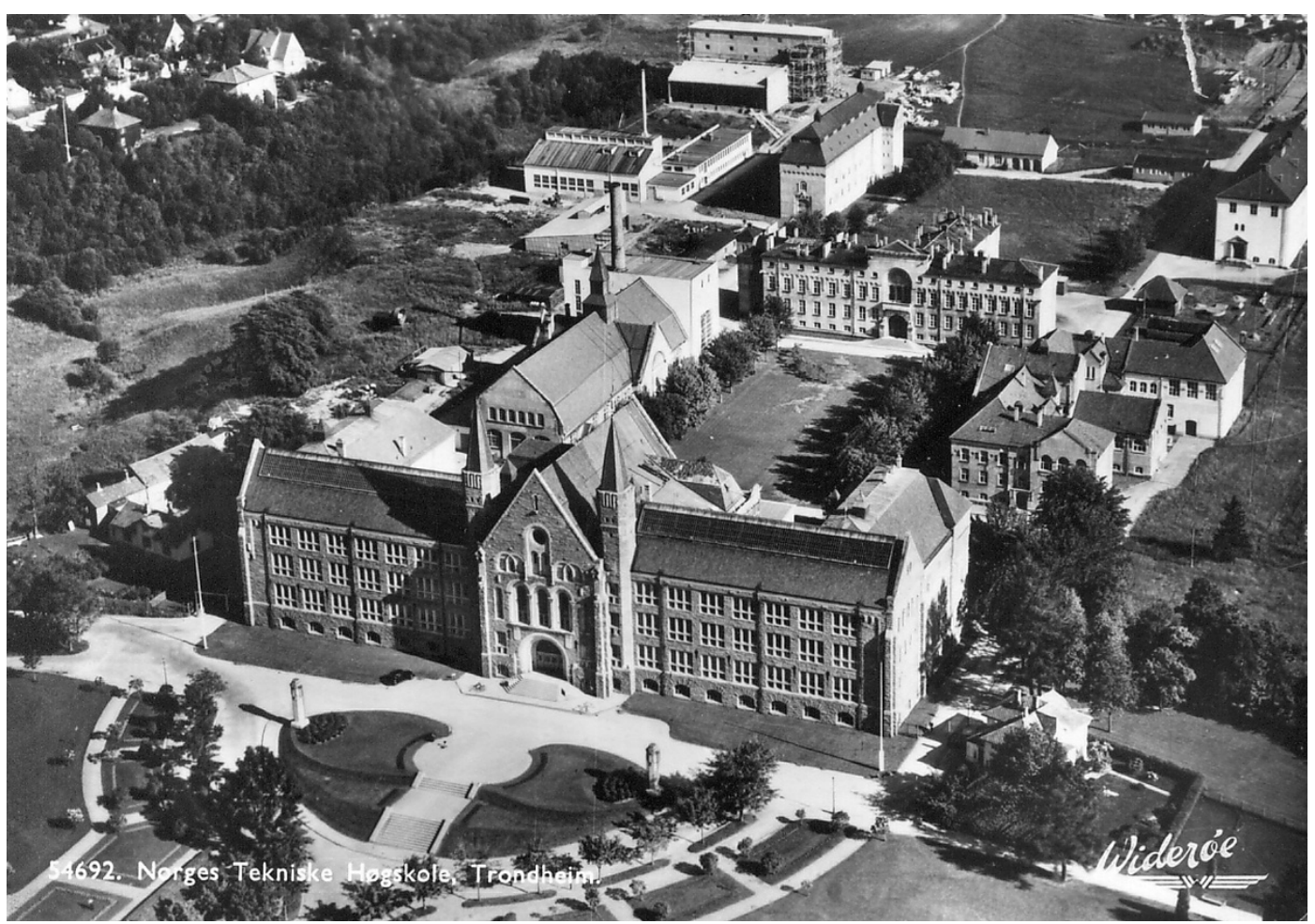

Figure 3: The campus of the Norwegian Institute of Technology in the 1950s.

particular, groups at the Massachusetts Institute of Technology (MIT) worked with principles of automatic control for weapon systems. The technical term became cybernetics, named after the Greek word kybernetes, which means steersman. This term was originally coined in the classic work Cybernetics: or Control and Communication in the Animal and the Machine (Wiener, 1948) by the MIT professor Norbert Wiener ${ }^{1}$. Cybernetics is later to become the Norwegian word for the field as well, and defined by Jens in (Balchen, 1997) as: "Cybernetics, which is an information science, is about how to control dynamic systems. A dynamic system can be everything from a vessel, a chemical reactor, an electric generator, a fishing tool, a fish shoal, an organ in the human body, or a group of individuals (animals or humans). To rationally understand and describe how complex systems behave dynamically by mutual interactions between their different parts is a fundamental premise in cybernetics."

Using his scholarship money, Jens travels to Yale University in 1950. After one year, he gets a MSc degree and an offer to work at the MIT Servomechanisms Laboratory. However, he discovers that he is in danger

\footnotetext{
${ }^{1}$ After visiting Balchen's group in Trondheim for four days, Wiener collapsed in Stockholm on the 18th of March 1964 while walking up the stairs at the Royal Institute of Technology. He was later pronounced dead on arrival at a nearby hospital (Conway and Siegelman, 2005).
}

of being drafted into service in the Korean War and quickly returns to Norway. He prefers to use his abilities to fight for Norwegian industry rather than to get mixed up in a war on the other side of the globe.

Despite his interrupted stay in the US, Jens establishes invaluable connections during the year at Yale. Among others, he befriends professor Albert Conrad who is an expert on controllable electric motors. Ten years later, Conrad is to become Dean of Engineering at the University of California, Santa Barbara (UCSB), where Jens will spend many sabbaticals in the coming years and whose control group still has strong ties to the cybernetics community in Trondheim.

\section{Servo Enthusiasts}

Back in Norway, Jens observes that servo engineering is starting to achieve a position there as well. He receives a scholarship from NTH for the period 19511954 to develop the discipline further. In 1953, the first lectures are given. The following year, the Control Laboratory (Reguleringsteknisk Laboratorium) is established at NTH and Jens is appointed associate professor (dosent) on July 1st 1954. In 1955 he also participates in the creation of a SINTEF unit in automatic control (SINTEF Avd. 48 Reguleringsteknikk), which in the following years will play a key role in in- 


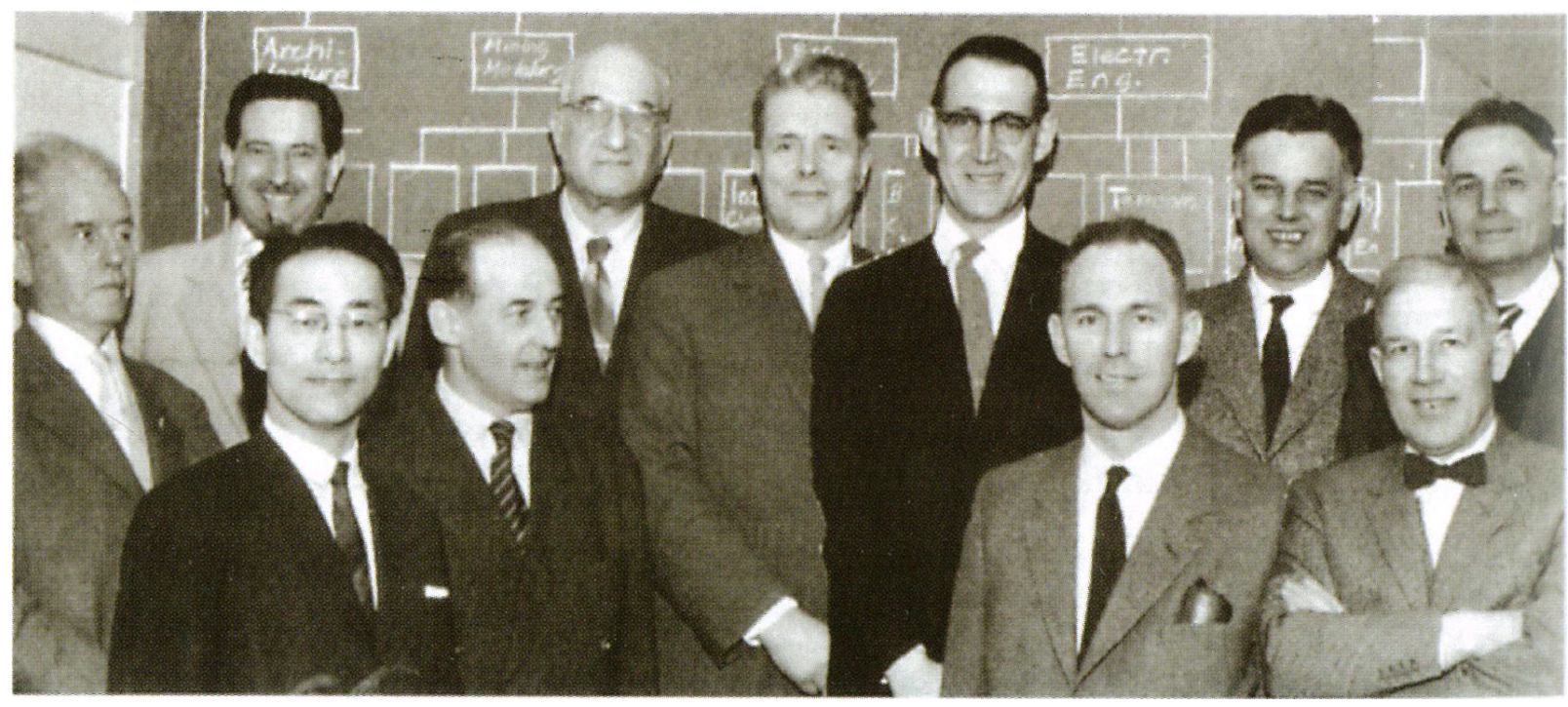

Figure 4: The IFAC Executive Council is gathered in Norway in 1961. Young Jens is located in the first row, second from the right. To his left stands Harold Chestnut, the first president of IFAC.

dustrializing the ideas coming out of his group.

Servo engineering also achieves a central role in NTNF's strategies. The field is new, it is visionary, and it has obvious applications which are important for Norwegian industry. Toward the end of 1954, NTNF thus establishes a committee called the Feedback Control Committee (Servoteknisk Utvalg) in order to evaluate how the new discipline should be handled. Its members include young and ambitious idealists who dream of automated factories supporting an increasingly modernized Norway. These servo enthusiasts internally joke that they belong to 'The Panel for Modern Things'. Jens is one of them, together with strong personalities such as Karl Holberg from FFI and the committee leader Haakon Sandvold, who is later to move on to become a major industrial leader. These men form a core group within the discipline and will have great influence for decades to come. More details about their activities can be found in (Kvaal, 1991), (Kvaal, 1992), (Wicken, 1994) and (Kvaal, 2009).

In parallel with the buildup of research activities, the servo enthusiasts feel the need for an informal meeting place. At the beginning of 1954 some of them gather for the first Servo Meeting (Servomøtet), which is to become an annual arrangement attracting researchers and engineers from all over the country to discuss and exchange information about recent developments within the discipline.

Internationally, research groups are quite isolated at this time, they have few dedicated journals to publish in and few meetings are held. However, in September 1956 this situation is about to change when an international control conference is arranged in the German city of Heidelberg. Jens is one of 30 participants who sign a resolution to create an international organization of automatic control, simultaneously pledging to also promote the formation of associated national organizations. The International Federation of Automatic Control (IFAC) is born the following year, with the American Harold Chestnut serving as its first president. Modeled after the United Nations (UN), IFAC is a multinational federation of national member organizations (NMOs) concerned with automatic control, with only one NMO allowed per country. By organizing congresses, conferences, symposia, workshops, and technical meetings, IFAC aims to "... serve all those concerned with the theory and application of automatic control and systems engineering." ${ }^{2}$ Jens becomes a member of the IFAC Advisory Committee in 1958 and proceeds to serve its various committees for decades.

Inspired by the establishment of IFAC, the servo enthusiasts continue to strengthen their network when they found the Norwegian Society of Automatic Control (Norsk Forening for Automatisering, NFA) in 1958 (Ryvik, 2008). Its purpose is to advance cooperation between the Norwegian control communities, strengthen their contact with international communities, contribute to competence building, and promote the field among the general population. NFA becomes the Norwegian NMO in IFAC, with membership open for companies, institutions and also individuals. The society soon assumes responsibility to arrange the an-

\footnotetext{
${ }^{2}$ The terms servo engineering, automatic control, cybernetics and systems engineering are all more or less synonymous.
} 


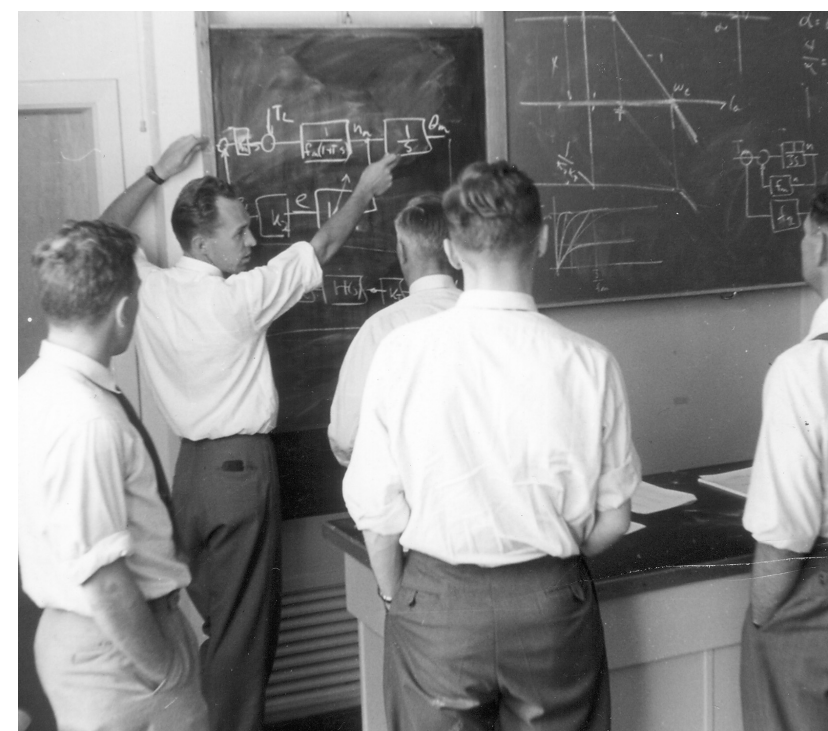

Figure 5: Jens lecturing on block diagrams in 1956.

nual Servo Meeting, which to this day is one of its flagship seminars. In 1992, Jens is appointed the first honorary member of NFA.

A professorship in control engineering is finally established at NTH in 1962. Jens applies and gets the position, which also marks the foundation of the Department of Automatic Control (Institutt for reguleringsteknikk). Control engineering now becomes an independent field of study at NTH, with Jens as its unrivalled leader. Odd Pettersen, who joined the department in the 1960s and today is a professor emeritus, recalls: "By virtue of his proficiency, creativity and ability to lead and inspire, Jens Balchen was the undisputed focal point of this enterprise. Although he faced much opposition from more conservative technologists, not least at NTH, he managed to forge important contacts and succeeded in getting the department accepted as the center for research and teaching in automation and control engineering in Norway, and also as a 'locomotive' for applying this technology in the industry and society at large." 3

\section{Machine Tools, Process Control and Automation for Ships}

Since Norway has a comprehensive process industry and a large shipping business, it is natural for the department to be concerned with these areas. The researchers work on developing new methods for au-

\footnotetext{
${ }^{3}$ Excerpt from Pettersen's speech at Jens' funeral on the 17 th of April 2009.
}

tomation of processes within the electrometallurgical, wood-processing and petrochemical industry. The goal is to increase productivity and quality.

The very first industrial project is contracted by the Ålesund-based shipyard A. M. Liaaens in 1954. The task is to develop an electrohydraulic control solution for a screw propeller to achieve a constant torque load on the diesel engine. Then follows a project where the challenge is to control processes for oil-product refinement at DeNoFa. The scope is large.

Control of machine tools also becomes an important area. In a collaboration between the control- and machine-oriented communities at NTH and SINTEF, Kongsberg Weapons Factory (Kongsberg Våpenfabrikk, KV) is able to develop its first controlled machine tool. The activity is considered unique, nationally as well as internationally, and in the following years more projects concerning machine tools and robots are pursued. The projects are based on the recognition that large, complex machines can be controlled by small, programmable computers that are under development.

From 1952, Jens leads a pioneering effort to build one of Norway's first electronic computers DIANA (DIfferential ANAlyzer). Its first stage is finished in 1954 based on experience from Yale and money from NTNF. Although DIANA is the first computer at NTH, Balchen only sees it as a means to an end (Nordal, 2009). He is not interested in computer development for its own sake, but strongly advocates computerbased control. Jens' attitude is illustrated through his statement in (Balchen, 1997): "The computer is the most important component in a cybernetic system."

\subsection{Comtec}

In 1965, Jens and his staff at NTH and SINTEF are eager to push new concepts for advanced process control and automation out into the industry. Concepts that have been developed over a period of ten years. His group combines hardware, software and technical equipment in a system able to control many processes at the same time, also more flexible, precise and reliable than conventional technology. A key component in their setup is the minicomputer PDP-8 from the American company Digital Equipment Corporation (DEC).

For demonstrational purposes, a prototype of the new system is installed at the cement mill Dalen Portland Cementfabrikk in Brevik. Over 100 Norwegian industry leaders show up for a demonstration in the autumn of 1966. However, no orders are placed despite many words of praise. The NTH/SINTEF engineers become frustrated. They believe that their system has a great potential for Norwegian process industry, which at this time is quite primitive with conventional au- 


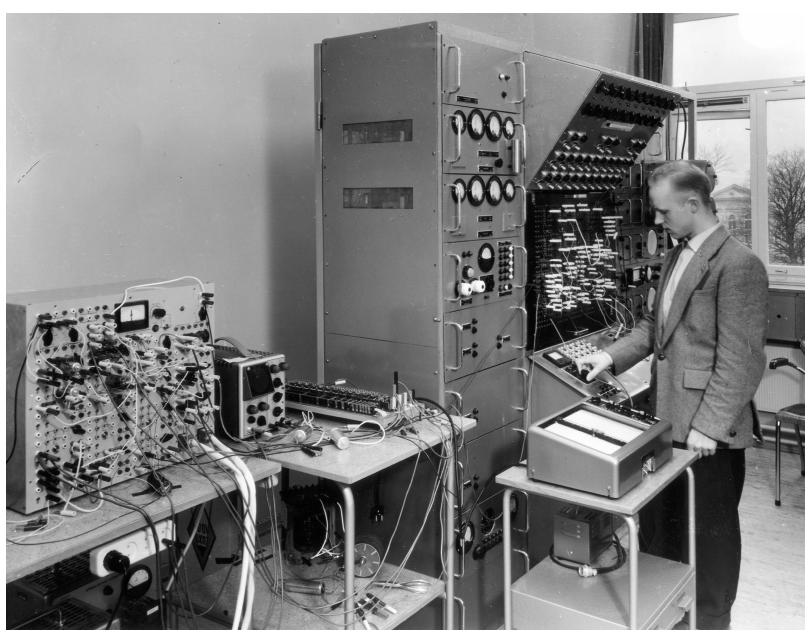

Figure 6: The analog computer DIANA is built as a tool to solve differential equations for control purposes.

tomation technology relying mostly on hydraulic and pneumatic components. In addition, they want to show that their NTNF-financed research can result in commercially viable products, especially at a time when NTNF plans to channel more of its funding directly into the industry and thus bypass the research institutes.

Toward the end of 1966, Jens and his colleagues take matters into their own hands when they suggest establishing an independent automation enterprise in Trondheim. The news is particularly met with opposition from the company Noratom and its supporters. Noratom was founded in 1957 as an attempt to commercialize research on nuclear energy carried out at IFA. At this time, such energy technology was viewed to be very promising. The company gradually acquires experience and skills with control and automation technology through its work with nuclear research reactors in Norway. However, the nuclear energy program starts losing support in the middle of the 1960s, and Noratom must search for new activities to survive. Control and automation applications emerge as a natural choice. Noratom is also in a favorable position to Balchen's group since it is owned by some of the main industrial companies in Norway using process control technology.

Still, Jens does not want his budding enterprise to become a subdivision of Noratom, which is located close to Oslo. He fears that such a development will entail more NTNF money to SI in Oslo instead of SINTEF in Trondheim. Balchen therefore forms an unusual alliance with the Trondheim-based company Nobø, a producer of zinc buckets, electric radiators and office furniture. It so happens that in a period of economic growth, Nobø's leadership wants to move into electronic products. Through clever arguments for the need of strengthened ties between research and industry, Jens is able to convince both NTNF, SINTEF and Nobø about his vision of an automation company located in Trondheim. As a result of these activities, Computer Techniques (Comtec) is founded in late May 1967. Seven researchers from SINTEF Avd. 48 Reguleringsteknikk jump on the bandwagon.

However, it soon becomes apparent that Comtec struggles with the installation of its advanced automation systems, losing money on most of its contracts. There is a gap between the existing equipment and new technology that takes too much time to bridge. In addition, the $4 \mathrm{~K}$ internal memory of the PDP-8 computers proves to be too small. To overcome such limitations, programs must be written directly in assembly code which is hard to read and difficult to adjust. Some describe the process as using a shoehorn to get all the programs to fit. Both advanced functionality and more time is lost. SINTEF also does not follow up on its promise to be a knowledge supplier and problem solver for Comtec. Neither does NTNF support the company's efforts. In 1972, Comtec's automation adventure is over. The reason is not that the customers have been displeased with the installed systems, but the company has not been able to make profitable deliveries nor gain access to the main actors in the Norwegian process industry. Commercial success is not just about sporting the most advanced technology.

Noratom is quite a different story. Owned and backed by many of the important process industry companies, it takes another approach to automation. Noratom starts by delivering comparatively simpler systems. Systems that fit well with the existing equipment. Elkem receives its first installation in 1969, followed by Bremanger Smelteverk, Christiania Spigerverk and Norsk Hydro. Gradually, the company builds up more advanced expertise and also starts using the Norwegian-built minicomputer NORD-1 delivered by Norsk Data (ND). NORD-1 proves to be much more applicable than the PDP-8. Noratom ends up outperforming Comtec and becomes the main supplier of Norwegian control and automation equipment in the 1970s. Further details about the struggle between Comtec and Noratom can be found in (Østby, 1989), (Østby, 1990), (Østby, 1991) and (Wicken, 1994).

However, all is not lost for Comtec. In 1971, the company is able to obtain funding for a reorganization toward computer-controlled systems for the typographic industry. The new strategy soon pays off. At the end of the 1970s, Comtec is the largest supplier of such equipment in Europe. In 1980, ND buys its rival and continues the activities through ND Comtec. 


\subsection{Haugvik and Taimyr}

In parallel with the development of new automation technology for the process industry, work is underway to develop computerized ship automation systems. Again, Jens and his group at NTH/SINTEF play a key role in the events. Noratom and Norsk Data are also important participants in the developments leading to the success of the Norwegian ship automation company Norcontrol. Detailed accounts of these activities can be found in (Høivold, 1984), (Overbye, 1989), (Wicken, 1994), (Høivold, 2003) and (Bjerva, 2006).

In 1959, four young Norwegians visit the University of California, Berkeley (UC Berkeley). Hailing from different research communities, the one thing they have in common is a vision for coupling automation technology with the Norwegian shipping industry. At this time, Norway has the fourth largest fleet in the world. However, the ship owners are conservative and do not readily welcome technological change.

Two of the Norwegians, managing director Jan Getz from the Institute for Ship Research (Skipsteknisk forskningsinstitutt, SFI) and NTNF scholar Arild Økland, have a maritime background. The other two, servo enthusiasts Ibb Høivold from the Chr. Michelsen Institute (CMI) and Jens from NTH, do not. This combination of backgrounds will prove to be very fruitful.

By chance, it is discovered that the US Maritime Administration (MARAD) has started an extensive investigation into ship automation technology. The ultimate goal is to develop an unmanned ship. A preliminary goal is to reduce ship crew by a third.

The Norwegians get excited. Already in March 1960, SFI applies NTNF for funds to carry out a theoretical ship automation study. Being a trade institute for the shipping business, with shipbuilders, shipowners and the classification company Det Norske Veritas (DNV) as contributing members, SFI envisions an incremental development based on conventional automation equipment. Balchen and Høivold are a bit more ambitious and want to see computer-based automation technology in practical use as soon as possible.

After a visit by Høivold in the autumn of 1962 , SFI invites its shipowners to place a vessel at the researchers' disposal for automation experiments. It turns out no one is willing to take the risk. However, in 1963 Høivold is able to convince his new employer Norsk Hydro to make one of its ammonia tankers available. As a result, NTNF grants funding for a new research project led by Høivold.

The main goal is to create an unmanned engine room onboard the M/S Haugvik. The project work is distributed among SFI, SINTEF, Norsk Hydro and DNV. For reasons of availability, applicability and reliability, conventional automation equipment is chosen

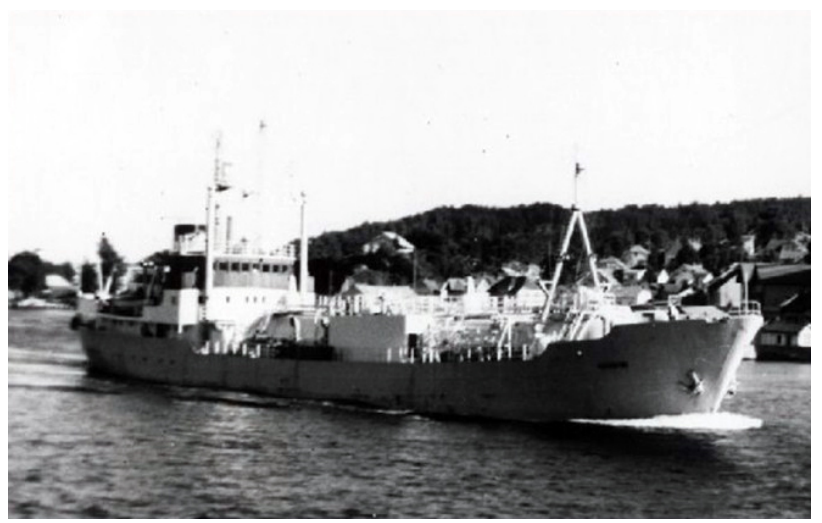

Figure 7: Norsk Hydro's ammonia tanker M/S Haugvik is retrofitted with experimental automation technology to enable unmanned engine rooms. Courtesy of DNV.

over electronic components. In anticipation of suitable computer-based systems, a rapid development founded on well-known technology is pursued. Mixing the views of Getz and Økland with those of Balchen and Høivold, this choice proves to be a smart move. In particular, it prepares the ground for the later introduction of more advanced technology.

In October 1964, an enthusiastic captain docks Haugvik by remote control. At this time, DNV has already begun evaluating the safety and reliability of the new installation. Early in 1966, the company's work results in a new class for automated ships, the "engine zero" (E0) class. E0 represents pioneering work and is a world's first. More importantly, the class enables industrial use of the newly developed technology.

Observing the progress of the Haugvik project, $\mathrm{KV}$ and Noratom also want to get into ship automation. Together with Norsk Hydro, these companies join forces to establish Norcontrol on the 1st of April 1965. Ibb Høivold is appointed general manager of the joint venture, which sets up shop in the old naval town of Horten.

The first product to be developed is a new bridge control system for E0. The first order comes in 1967. But Norsk Hydro does not want to finance the development costs any longer. As a result, the large industrial company withdraws as a partner. Shortly thereafter Noratom suggests a merger with Norcontrol, which goes through in June 1967. The newly formed company has an impressive board, with 3 representatives from the shipping industry. Høivold becomes manager of the ship automation division.

Almost a year earlier, an application has been sent to NTNF for funding of a new trial project, this time for 
research on computerized ship automation. Balchen strongly supports the project through his position in NTNF's Feedback Control Committee. Norcontrol is to be in charge, with SINTEF and SFI as collaborators. A few months before the merger with Noratom, NTNF grants money to the project. The time has now finally come to start moving beyond conventional automation technology.

The hunt for a test ship is soon underway. It turns out to be easier than with Haugvik. M/S Taimyr is a cargo liner under construction in Japan, contracted by the Norwegian shipowner Wilh. Wilhelmsen.

The project also needs a suitable computer. At this time, some researchers at FFI have plans to commercialize promising new technology. In the autumn of 1967, Norcontrol aids in the establishment of Norsk Data by purchasing stocks and buying the new company's first computer NORD-1. This gambling turns out to be very successful.

The Taimyr project results in a revolutionary mix of advanced ship automation functionality: A computerbased E0 system, a bridge control system, an automated power management system, a system for monitoring the load condition, and the world's first radarbased anti-collision system (automatic radar plotting aid, ARPA). In addition, the ND computer shows a remarkably good reliability with more than one year between failures.

Sailing from Cape Town to various ports in Europe in 1969, Taimyr arrives in Oslo on the 2nd of October. A big press conference is held with the Norwegian Broadcasting Corporation (Norsk Rikskringkasting, NRK) present. Captain Husum enthusiastically declares that: "With our installation we sailed more safely in dense fog than without it on a clear day!"

The project represents an astounding technological success. In the aftermath, NTNF decides to award Norcontrol exclusive rights to the developed technology. Today, the high-tech company Kongsberg Maritime continues the Norcontrol legacy.

Jens' group in Trondheim is vital to the success of the Taimyr project. Key engineers at Norcontrol such as Bjørn Bjorå, Terje Mikalsen and Finn Fjelheim are all recent graduates from his department. The NTH/SINTEF community also develops the NORD-1's operating system SINTRAN (SINtef+forTRAN) (Asphjell and Børresen, 2004). Jens contributes actively in shaping both the Haugvik and Taimyr projects as well as gathering support from NTNF. When the Norcontrol deliveries start picking up steam in the 1970s, Balchen has to ask nicely for Høivold not to completely empty his department for qualified personnel.

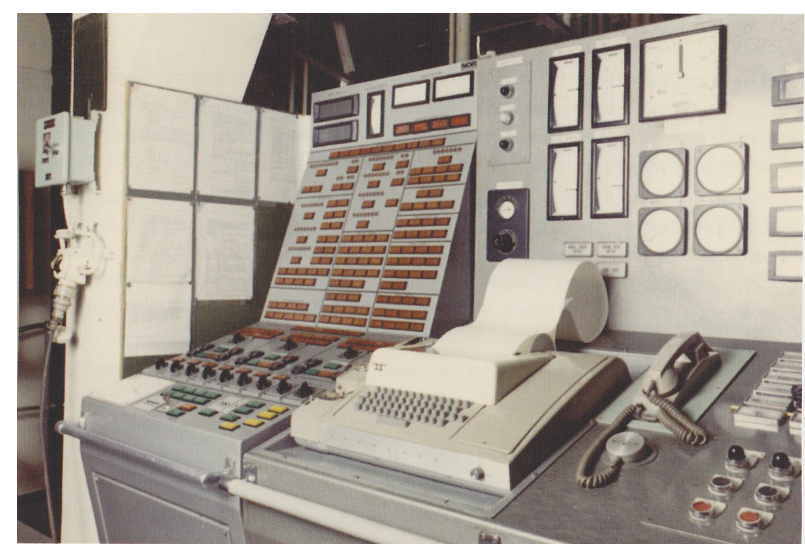

Figure 8: A prototype of a computer-based ship automation system onboard the M/S Taimyr. Courtesy of Kongsberg Maritime.

\subsection{Countryside Bachelor}

Toward the end of the 1960s, a large number of eager and competent candidates at Jens' department work with data processing, process control and ship automation, often with the result that they leave to start their own companies afterwards. New application areas are constantly appearing, inspired by the technological opportunities and the researchers' interests.

In time, 10-15 companies will emerge from Balchen's group. When asked about this achievement in 1994, Jens characteristically replies: "We are like a bachelor in the countryside. Participate in the conception, but once that's done we jump off and leave the delivery and upbringing of the offspring to others, before looking for a new chance!" Adding that: "The starting point for research at the department is that we're supposed to solve a problem for someone, not first make something and afterwards look for a need. We solve the problem through research and then leave the product development to the contractor." (Kittilsen, 1994a).

\section{Dynamic Positioning of Ships}

The concept of dynamic positioning (DP) is conceived in the early 1960s. DP technology is motivated by the need for accurate placement of ships for drilling purposes, at locations where it is practically impossible to deploy conventional jack-up barges or anchor spreads due to large water depths.

In 1961, the American drillship Cuss 1 becomes the first DP-capable vessel in the world (Faÿ, 1990). It maintains position offshore La Jolla in California exclusively by means of four steerable propellers. The control is manual, but later that same year the Shell 


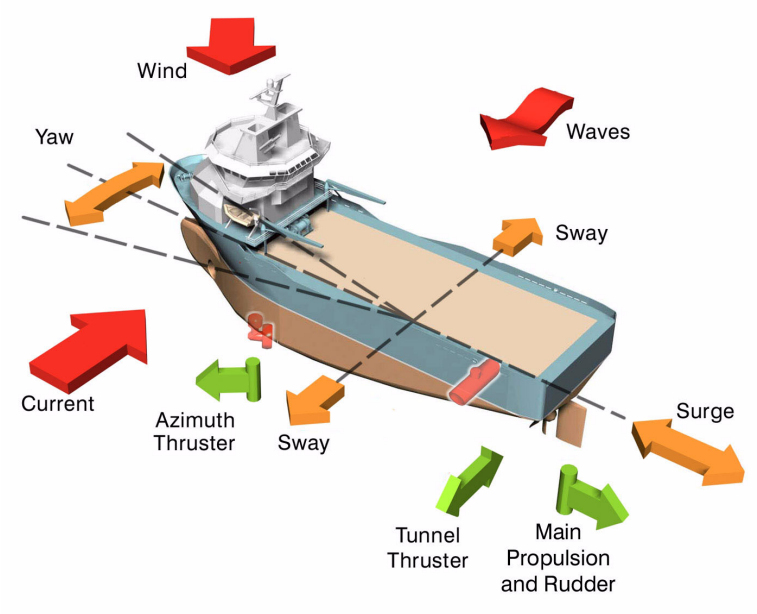

Figure 9: A DP vessel positions itself in the desired degrees of freedom (orange arrows) by counteracting the environmental forces (red arrows) through its propulsors (green arrows). Courtesy of Kongsberg Maritime.

Oil Company introduces the first computer-based DP system for its coring vessel Eureka. However, the technology is still only in its infancy.

While on a sabbatical at UCSB in 1967-1968, Jens learns about a project to equip the scientific drilling vessel Glomar Challenger with a DP system (Bjørnstad, 2009). He becomes convinced that such technology can aid in the emerging oil and gas activities on the Norwegian continental shelf. Balchen also believes the technology has great potential for improvement. In particular, he wants to use model-based estimation techniques to obtain enhanced navigation data from noisy measurements. The recently developed Kalman filter, which already has proven itself in the American space program, seems a prime candidate for the job.

Back in Norway, Jens gets several of his students to explore Kalman filtering and other DP-related issues in their thesis work. From 1971, he also starts lobbying $\mathrm{KV}$ for developing a commercial product. At first the company is not interested. It makes a survey which concludes that the Norwegian market is too small for such a product. Not unexpectedly, the lukewarm response does not deter Jens. He continues to promote DP with great enthusiasm.

Finally, in January 1974 a joint effort involving NTH, $\mathrm{CMI}, \mathrm{KV}$ and the Horten-based electronics company Simrad gets underway. KV administers the project while Jens pushes it forward.

The following year, the KV subsidiary Albatross is founded to develop and deliver DP systems. The name reflects on the large seabird's ability to glide for hours without rest, rarely seen on land except for nesting. Albatross soon receives its first order.

At this time, the American company Honeywell has 80 percent of the global market for dynamic positioning. A market which is quite small, with only 3 to 4 installations per year. One of Honeywell's customers is the Norwegian shipping company Stolt-Nielsen. Their multipurpose vessel M/V Seaway Falcon sports the Honeywell Automatic Station Keeping (ASK) system. However, Stolt-Nielsen is discontented with the Americans' bulky system and expensive service. As a result, the company contacts KV for their next installation. The contract is signed in November 1975.

Using a coated plywood box with a Simrad sonar screen in front, Albatross markets its first DP product at the 1976 Offshore Technology Conference (OTC) in Houston, Texas. Later that same year, Jens and his coworkers Nils Albert Jenssen and Steinar Sælid publish their first academic DP paper (Balchen et al., 1976). Combining an entrepreneurial and customercentered Albatross with a unique DP concept from NTH/SINTEF will soon dethrone Honeywell. The first prototype is installed on the Stolt-Nielsen diving support vessel M/V Seaway Eagle on May 17th, 1977.

As stated in (Balchen et al., 1980), a DP system should "...be designed to keep the given vessel within specified position limits, with a minimum fuel consumption and with minimum wear and tear on the propulsion equipment." The use of Kalman filtering helps achieve this goal. Based on a mathematical model of the vessel to be positioned, as well as the characteristics of the environmental influence of waves, wind and current, the estimator is able to distinguish between the rapidly-varying oscillations which over time cancel each other out and the slowly-varying drift pattern. Only the latter motion component is relevant for a vessel which wants to avoid unnecessary energy waste.

In addition, the Kalman filter allows several different position reference systems to be used simultaneously, combining the various outputs to achieve an optimal position estimate. This property is very important since different measurement principles utilizing different transmission media yield a higher reliability than a single solution. Honeywell's DP system mostly relies on hydroacoustics alone, which inherently makes it more unreliable. And in case all the navigation systems should fail at the same time, the Kalman filter is still able to provide a rough estimate of the vessel position based on its mathematical model.

Finally, the Kalman filter continuously predicts how the wind will affect the vessel. This information is used to proactively counteract wind disturbances by feedforward control, making it difficult for the wind to 


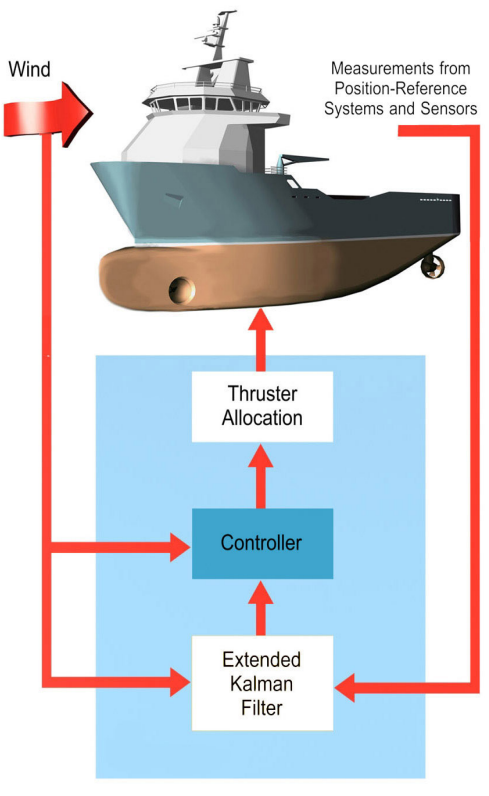

Figure 10: The control principle of a DP system. Motion data are processed through a modelbased Kalman filter to extract the slowlyvarying components. By comparing this information with the desired motion (feedback), and also using the predicted wind effect on the vessel (feedforward), the controller gives commands to the propulsors on how they should behave in order for the vessel to keep its desired position and orientation. Courtesy of Kongsberg Maritime.

push the vessel off position. In contrast, the principle of feedback can only be applied as a response to events that have already occurred. At this time, all Albatross' competitors only employ feedback control in their DP solutions. According to Balchen, dynamic positioning without feedforward control is like steering a car by watching the centerline through a hole in the floor (Bjørnstad, 2009).

In sum, the Albatross DP system is more reliable, more robust and saves more fuel than anything the competition has to offer. In addition, it is very userfriendly with a 'one button for one function' approach (Ryvik, 1999). As a result, every new DP installation in 1980 is delivered by Albatross. In 1981, half of the 80 operational DP systems worldwide have been installed by the company. Albatross then moves on to capture more than $80 \%$ of the market in the 1980 s. Balchen, Jenssen and Sælid continue to refine their DP algorithms in (Balchen et al., 1980) and (Sælid et al., 1983). Following these achievements, Jens is rumored to have said: "There are only three people in the world who truly understand control engineering, and the other two are former students of mine."

At the end of 1999, the Albatross positioning system comes second in a vote among Norwegian engineers over the "Engineering Feat of the Century" ("Århundrets Ingeniørbragd"), a competition arranged by the leading engineering magazine Teknisk Ukeblad. Important criteria include technical boldness, imagination, innovation and social significance. The gigantic Troll A platform, the tallest structure ever moved, is voted number one.

In time, DP functionality evolves to include lowspeed path following applications such as cable and pipe laying (Kittilsen, 1994b). The technology also extends into other maritime segments to serve passenger and cargo vessels, research and survey vessels, as well as naval vessels. In 2003, over 1000 DP-capable vessels are in operation all around the world (Bray, 2003).

Today, similar to Norcontrol, the heritage of Albatross is furthered by Kongsberg Maritime, one of the world's largest suppliers of maritime electronics.

\section{The Mild-Chaos Principle}

When Jens looks back on this period, he values the access to research money. He had what we today would call a drinking straw into the cash box: "We were never short of resources. I sat in the Feedback Control Committee in NTNF for 25 years and allocated money."

Jens did this with the blessing of NTNF's leader Robert Major. Major sat on the money bag and had a liberating, unbureaucratic leadership style. Jens describes the process like this: "We had short meetings, described our work and calculated the need for money. Major made fast decisions. Payment took place immediately."

Robert Major surrounded himself with a very small organization. He chose to use a set of specialist committees instead of employees. According to Jens he played the committees like a piano. "Major believed in us and gave us free hands, provided that we produced results. Which we did. Norway has never been as competent as then. The period 1955-85 was the best in modern history. We then lay the foundations of what we have based our lives on since. It was during these years that Norway became the world's best country to live in."

It was possibly so-and-so with the legality of Robert Major's research council. In the Feedback Control Committee, the billy goats weren't positioned in front of the oat sacks, they were sitting right in the middle of them. "We were attached directly to the nervous system," Jens admits. But the legality problem didn't worry him. "We knew what we were doing. Is it better 
to use people who don't? That's what they do today. Everybody can see how that works. Robert Major ran an enlightened dictatorship, but he got things done!"

It was a nice time also at the university campus at Gløshaugen. Jens ran both the NTH department and the SINTEF unit by what he called the "mild-chaos principle'. The projects were legion and creative people were allowed to unfold themselves. "We performed online management and had a minimum of bureaucracy. Young engineers were hired at SINTEF, where it was easy to kick them out again if we had a shortage of projects. But we didn't fire that many," Jens says to soften the impression. "It wasn't necessary. We had plenty to do. And if somebody had to leave, the industry was ready to receive them."

\section{Modeling and Control of Fish}

In the late 1960s and early 1970s, cyberneticists start to get interested in biological systems: How to compensate for defect glands with controlled dosage? How to make artificial prostheses and organs? How to regulate medication automatically? The problem is that the health sector doesn't have any free means available. It is difficult to get support for research. Jens asks himself which biological area in Norway is positioned on the income side of the national account? The answer is fish.

\subsection{Ocean Bio Models}

Jens is a strong advocate of model-based estimation. He wants to develop ". . a model-based system for estimating the present and predicting future ocean resources and providing data for controlling the harvesting facilities," believing that mathematical modeling "... is the most effective single tool to help understand the basic internal mechanisms of ocean subsystems and the interaction between such subsystems." (Balchen, 2000). Such a model-based system is the goal of the Ocean Bio Models (Havbiomodeller) project, which starts in 1975. Specifically, Jens wants to model the marine ecosystem of the Barents Sea to promote purposeful resource management.

The ocean subsystems that interest Jens include models of ocean hydrodynamics and energy flow; models of nutrients, phytoplankton and zooplankton; population models; migration behavior models; and models of the measuring processes. Ultimately, he wants to develop an online estimator for the entire ecosystem, employing buoys, vessels, aircraft and satellites as measurement nodes. Coupled, dynamic models of fish stocks are to replace the uncoupled models in use by the established marine research communities, mod- els that for instance cannot explain sudden collapses in certain age cohorts.

Research ships are contracted to put out measurement lines in the Barents Sea. These lines are attached to floating buoys that are anchored to the sea bottom and have satellite communications. An unexpected consequence is that Russian naval vessels intercept the communication signals and take possession of some of the equipment.

However, this is not the only problem facing the ambitious project. Jens' systems thinking is very unfamiliar for the traditional marine research communities. The fact that he's not always a diplomat doesn't help either. He tells many a professor and research director how silly he thinks they operate when gathering thousands of water bottles from ships for analysis without coupling the results with other measurements through models and estimation techniques. Ultimately, his opponents are able to prematurely terminate the Ocean Bio Models project in 1983. In particular, the Institute of Marine Research (Havforskningsinstituttet) plays a central role in this process.

Yet, as often throughout his career, Jens proves to be ahead of his time and the project has major consequences. Numerical models for estimating the interaction between oceanographic conditions and the ecosystem are now being used, even by the communities that most strongly opposed his original project. Also, the project's ideas of ecological management currently constitute a cornerstone in both Norwegian and international fish resource management. Having acknowledged the poor predictions of the old age-cohort models, marine researchers now employ coupled fish stock models as originally advocated by Balchen and his group.

There is still a long way to go before fully implementing operational model-based estimators as envisioned by Jens, but current Norwegian efforts in this direction put the country at the international forefront of the development.

\subsection{Cyberfish}

Jens also thinks it must be possible to equip a fish with electronics such that it can be steered. He has experienced that a touch on the left side makes the fish swim toward the right. A simple control unit can ensure that the fish moves as desired. Based on the experience that a fish school follows a fish which has a simple and precise behavior, Jens believes that a robot fish can assume the function of a shepherd in the school. He steadily sees new opportunities on the horizon.

For a long time, the placement of the electronics constitutes a problem, until Jens discovers that it can be located in the fish's belly. It's spacious there, at least 


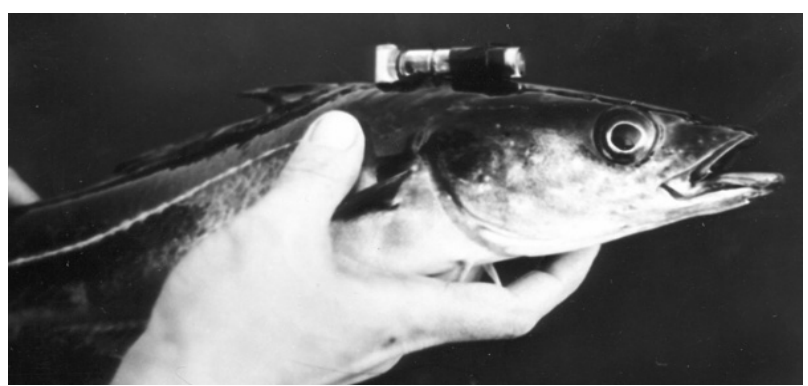

Figure 11: Controversial setup for fish experiments.

for larger fish. But it can also be mounted on the back, like a rucksack.

Jens builds a tank on top of the electronics department building at NTH. In this 'fish behavior laboratory' he tests his ideas. A Japanese daw shows particular suitability and is equipped with a backpack full of control electronics. With the help of ultrasound the daw receives information about where to move. And it does as it is told. Balchen also performs experiments to control the speed by sending impulses to the tail fin. The fish is called cyberfish. In Jens Balchen's head, cyberfish is the humans' secret agent among the fish. Commenting on the ethical aspects of the endeavor, Jens compares it to dog training and horse taming.

The possibilities that open up are many, and Jens imagines: I will get the fish to work for me. I can control it to go wherever I want. With electronics in the rucksack and a camera on the head, a salmon can perform much of the same work as a mini-submarine. The cost difference is colossal. While a mini-sub costs millions, the price of salmon is NOK 30 per kilo. It can't get any cheaper.

The fish farming industry is an obvious customer for Jens Glad Balchen's cyberfish. The fish can be steered to where the pasture is best. Maybe to Scotland. Or all the way to America. A pollack is big enough to carry a couple of kilos of electronics. And it's a patient creature that can survive for months without eating. However, Jens doesn't see any reason to torment the fish. It should be given time off now and then to relax and find food before the troops are gathered to continue the journey.

One day Jens receives a phone call from a journalist representing the Aberdeen Press and Journal. He has read about the cyberfish in the popular science magazine Gemini. Jens willingly talks about his visions, that the robot fish can be a shepherd, and that it can gather its school and swim to Scotland to graze there. Is it possible that the Norwegian shepherd fish can gather supporters in Scotland too, the journalist inquires. Absolutely! Not possible to tell how many will return. The interview with the Norwegian pro- fessor becomes a headline in the Aberdeen Press and Journal, and the reactions do not wait.

Members of the local Scottish Fisherman's Association Ltd. read the newspaper with horror and protest loudly. This Balchen must be stopped. Cyberfish will cleanse the coast of Scotland of fish. The fish will be led to Norway - as by a Hamelin rat catcher of the seas. The president of the organization will address the issue with the European Union. Ban the cyberfish! Jens comments to the Aberdeen Press and Journal that he can just go ahead. The president is in his own right to "make a fool of himself."

However, no invasion of cyberfish in Scottish waters takes place. Nowhere else either. Jens applies to the Research Council for funds over a 20-year period - not a single dime is granted. The industry doesn't trample down his doors either. "We went to the industry and said that this must be smart. Which the industry also thought, for that matter, but not enough to pay for the research."

The industry's lack of interest results in Jens reposing several of his patents. The cyberfish project is probably ahead of its time. "The industry is conventional, it doesn't want too many changes. In contrast to us, who only care about changes. It might not have worked. But it doesn't matter. If it hadn't been robot fish, the research would have spun out something else," says Jens.

\subsection{Other Fishy Adventures}

The ocean-modeling and cyberfish projects only represent a sample of Jens' adventures in fisheries and aquaculture. He is also involved in fish farming. An experimental facility is built in Hopavågen, a bay situated $120 \mathrm{~km}$ west of Trondheim. The research involves modeling and control of fish behavior. Jens spends a great deal of time finding out how cybernetics can be used for this purpose. "Few think of fish as a system-theoretic phenomenon. Inner functions, the interaction between individuals in a school, the mutual behavior coupling. How can the fish for instance keep an approximately constant distance between themselves?"

Every fish has a sensitivity for something - for example sound, light or smell. The school's sensitivity increases with the number of individuals - that is why the fish schools. A fish that loses its school does not survive. A question is: Can we control the fish behavior through conditioning, i.e., a mild form of training? In the beginning Jens does not really know what the knowledge should be used for. But if he is able to control the fish, he feels certain it can be used for something. Maybe to develop better tools?

He develops the idea of an electric fence consisting of sound and light pulses combined with electrodes 
that can shock the fish. The fish must learn that sound/light means discomfort, which is why it must stay away. The light fence is supposed to replace the net cage. Because Jens doesn't like net cages. Net cages are prisons tormenting the fish. Besides, they fall apart. New fish types for farming, like cod and halibut, do not thrive in net cages.

At a meeting with the steering committee of one of Jens' fisheries projects he encounters opposition from several of its members. Not everyone agrees with his ideas and hypotheses. Immediately following the meeting, Jens accidentally bumps into one of his research associates Bård Holand. Today an adjunct professor at the department, Holand is asked to come into Balchen's office. Jens is in a rather foul mood and complains about how incompetent and small-minded certain persons in the steering committee are. After a pause of thought he then proclaims with great enthusiasm: "I hate people whose profession ends on 'logist'... biologist, meteorologist, physiologist, sociologist..." While Balchen has another pause of thought, apparently trying to recall other 'logists', Holand cannot keep to himself but adds: ". . and technologist!" Almost horrified, Jens looks at Holand and exclaims: "What are you saying lad? We're the ones that have brought the world forward!"

Detailed accounts of Jens' use of cybernetic methods in fisheries and aquaculture can be found in (Balchen, 2000). When asked if he is satisfied with the results of these research efforts, Balchen is in no doubt: "No." Elaborating: "Very few are able to see the potential of this activity. Norwegian politicians lack visions. They are only good at creating new jobs in the bureaucracy. Those that have visionary power cannot function in a bureaucracy." (Asphjell and Børresen, 2004).

As a consequence of its increased scope, the Department of Automatic Control changes its name to the Department of Engineering Cybernetics (Institutt for teknisk kybernetikk, ITK) in 1972. Today, Fishery and Aquaculture Cybernetics is established as an independent field of study at the department.

\section{Supporting Ultrasound Imaging}

In the beginning of the 1970s, the physician Alf Brubakk and the engineer Rune Åslid are both awarded $\mathrm{PhD}$ scholarships to collaborate in the development of a mathematical model of the human cardiovascular system. The project represents medical-technical pioneering work and is a collaboration between the general hospital in Trondheim and NTH. Together with Rolf Rokseth from the hospital, Jens co-advises the research and gives the two students a small corner in a lab at his department.
The project starts at a time when model-based estimation and Kalman filters are hot research topics. The PhD students consequently start working within this framework, but it soon becomes apparent that too few measurements are available. Having access to only blood pressure and electrocardiogram (ECG) information is not sufficient. A challenge is to measure the blood flow coming out of the heart, and ultrasound turns out to be an interesting principle to explore.

Motivated by this challenge, the electrical engineer Bjørn Angelsen receives a PhD scholarship at NTH in the period 1972-1975 to build a purposeful measurement apparatus. The instrument is constructed, but is large, chunky and full of knobs in the front. Cardiologists are shocked when introduced to this monster. Angelsen needs more money for miniaturization.

In the autumn of 1975, a meeting is set up with Jens and Knut Grimnes, who is managing the SINTEF unit on automatic control. The two men have faith in the project and decide to contribute substantial funding to develop 10 smaller units with fewer knobs and a more appealing exterior. Together with a group of bright and motivated MSc students in engineering cybernetics, Angelsen builds these units during the summer of 1976. All of them are sold, covering the original expenses.

The clinician Liv Hatle soon sees the potential of the ultrasound-based instrument to non-invasively diagnose heart diseases. An electronics company is contacted to develop a commercial product, which sees first daylight in 1979. Today, this company goes by the name GE Vingmed Ultrasound and is world-leading on advanced ultrasound-based imaging systems. Applications range from heart diagnostics and surgery to cancer detection and fetal diagnostics. Equipment worth billions of NOK has been sold. Their latest invention, the Ipod-like Vscan, was named one of the 50 best inventions in 2009 by Time Magazine and also voted "Engineering Feat of the Year" ("Årets Ingeniørbragd") for 2009 by Teknisk Ukeblad (Aadland, 2009). The main architect behind Vscan is Kjell Kristoffersen, one of the cybernetics students who helped Bjørn Angelsen miniaturize his ultrasound machine back in 1976 .

Today a professor in biomedical engineering and an adjunct professor in medical cybernetics, Angelsen characterizes Balchen as an incredibly inspiring and visionary man who made this development possible. Without Jens' decision in 1975 to fund and support his work the activity would have died out. The original idea of model-based estimation of the cardiovascular system thus resulted in an instrument which became a fantastic success story for high-tech medical industry in Norway. 


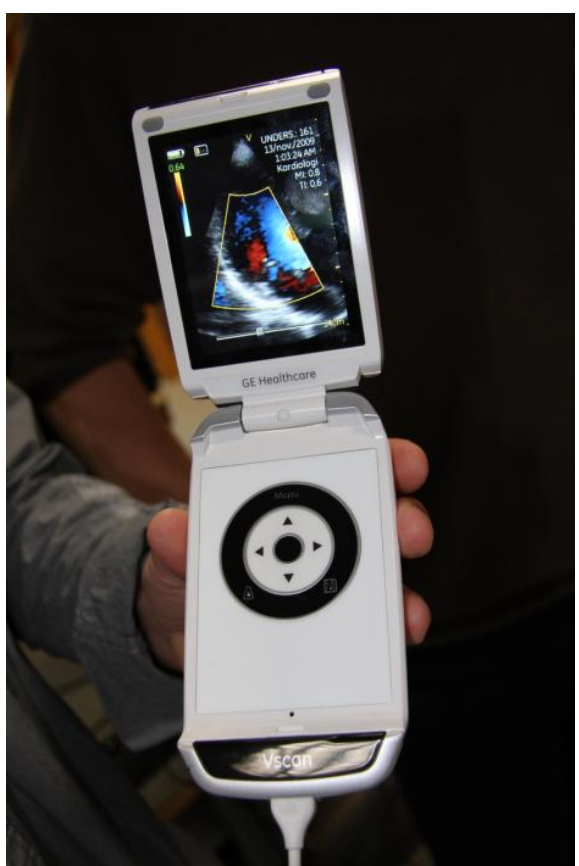

Figure 12: Vscan is a pocket-sized ultrasound machine from GE Vingmed Ultrasound in Horten. Photo: Camilla Aadland.

\section{A Creative Designer}

"I don't necessarily see myself as a researcher," Jens says. "I am more of a creative designer. As an engineer I started with a problem related to a product or a process. And I use the methods I know to find solutions."

As an engineer, Jens is concerned with business and value creation. We must have something to live by in Norway. The majority of people in our society are consumers, they are dependent on others to be creative. The oil wealth is dangerous, it makes Norwegians idle.

Is Jens performing applied research? He does not appreciate the classification. Much of the theoretical work can probably be called basic research. The publication list is long and he has surely written equations that no one else has written before. Jens probably has a Norwegian record in supervision of $\mathrm{PhD}$ students. 61 have graduated. "But first and foremost I have been concerned with theories about something useful. We studied how an aluminum plant worked and looked at the possibilities of improving the processes. It was complicated enough. Much applied research is very advanced from a theoretical viewpoint."

Jens believes that many of his colleagues are too concerned with theories. When they publish something they feel that they have finished the task. "It has never been my style. I think the really interesting part is when the theory gets realized in practice."

\section{Bureaucracy Rising}

Toward the end of the 1980s something happens with research in Norway that upsets Jens. To an increasing degree, the resources get routed to other purposes than research. The universities are entering a period of administrative buildup. The research council moves in the same direction: "Bureaucracy invents problems. In this way they create needs for their own functions. It has become an unparalleled paper mill," Jens sighs and thinks with wistfulness back to the days when he only needed to travel to NTNF to 'get' money.

The application bureaucracy conflicts with the scientist's mentality, says Jens, and adds that he abhors it. We've got a threshold for approval of an application that lies far above the critical level of a gifted, creative researcher. Bureaucracy makes researchers spend millions on writing applications. Subsequently, the research council spends millions to evaluate them. "Last year I submitted five applications and received good evaluations on all of them - before they were rejected. If I'd got the money they spent to process and reject my applications, I'd probably managed well!"

Is there an alternative? "Sure. My advice is simple: Shut down the bureaucracies and give the money directly to the professors. They know best how to spend the money right."

The professor is the cornerstone in Jens' picture of creative research groups. And the professor must be granted freedom. Give each professor 5 million per year. That corresponds to the funding of $5 \mathrm{PhD}$ students. Evaluate the professor every 5 or 10 years to see if he still holds up. It's as easy as that.

Naturally, a condition must be that the professor holds up. When the university hires a professor, it must spend time to find one that is well qualified. "We must have capable people. A professor must be chosen with care because he will be awarded privileges. If the professor doesn't hold up, the research won't either."

Unfortunately a lot of research in Norway doesn't hold up: "Very much of what is called research are just simple data collection exercises. We count things, the number of intercourses for example, and correlate with the temperature in the bedroom. Suddenly you are a researcher."

Much of what currently sails under the banner of research is pure 'buttonology', according to Jens. He refers to the phenomenon that when a mother puts her small child on the floor with a box of buttons, it instinctively starts sorting the buttons according to color and holes. "It can be useful to count buttons, but don't call 
it research," says Jens, who calls for someone with the courage to say what is good and bad research.

The centers of excellence in Norwegian research are perhaps a step in the right direction. Perhaps. "Imagine a desert with a small oasis where there is water. That's the centre of excellence. In Trondheim, three such oases have been established. That means most of it is desert. And perhaps more desert than otherwise since the meager resources are led into the three oases."

Jens thinks it's frightening that we don't spend more on research in Norway. If we should stake our fortune on something, it should be advanced education and research in order to cultivate capable people and good products. It is not acceptable that research becomes a balancing item on the national budget.

"Sometimes I feel that we should have a break from democracy. Insert a caretaker government which gets things done. But I can't say that out loud..."

\section{A New Research Direction}

When the degree of "doktor ingeniør" (a specific engineering doctorate) is introduced in the 1970s, Jens sees a considerable opportunity to establish organized $\mathrm{PhD}$ research at the department. As a tool for presenting the associated results to the world community, he initiates the establishment of a research bulletin dealing with the topics of modeling, identification and control. In 1980, the first issue of the quarterly-published journal Modeling, Identification and Control (MIC) appears. To this day, this publication remains the only technology journal in Norway.

In the middle of the $1980 \mathrm{~s}$, Jens' new research strategy is aided by the former NTH chancellor Inge Johansen who has recently become the managing director of NTNF. Johansen strongly advocates using an increasing amount of the council's funds for research performed by $\mathrm{PhD}$ students, particularly at NTH. As a consequence, ITK's production of PhD students steadily increases as several new doctoral programs are started. In the period 1985-1995, these programs include (Balchen, 1997):

- 1985: Method Program for the Process Industry (MIP) with $9 \mathrm{PhD}$ scholarships.

- 1987: Program for Robot Research at NTH (PRORO) with 15 PhD scholarships.

- 1988: Program for Process Modelling, Instrumentation and Automation (PROMIA) with $9 \mathrm{PhD}$ scholarships.

- 1991: Program for Underwater Robotics (MOBATEL) with $11 \mathrm{PhD}$ scholarships.

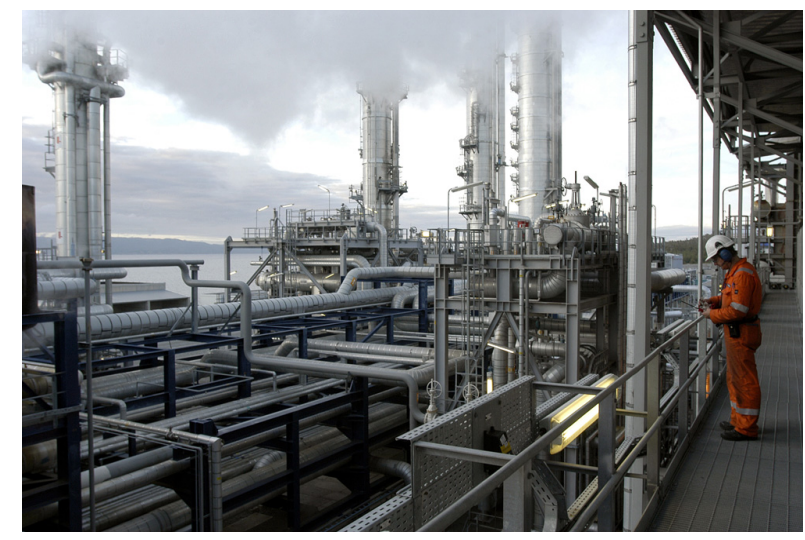

Figure 13: Statoil's process plant at Tjeldbergodden depends on computer-based process control systems. Photo: Harald Pettersen.

- 1991: Intelligent Cybernetic Systems (IKS) with $4 \mathrm{PhD}$ scholarships.

- 1993: Integrated Production Systems for the Process Industry (INPRO) with $9 \mathrm{PhD}$ scholarships.

- 1995: Distributed Process Control (ORD) with 5 PhD scholarships.

A common feature for many of these programs is their interdisciplinary focus, which is a reflection of the interdisciplinary nature of engineering cybernetics itself. For example, PRORO involves groups from workshop technology, electrical power engineering and marine technology, while PROMIA involves chemical engineering, refrigeration technology and marine machinery. "It is on the boundary between the various sciences and interdisciplinary research groups that understanding and knowledge come into being, and where opportunities for new application areas are discovered. And it is on this boundary that the Department of Engineering Cybernetics is located," Jens says in 1994 (Kittilsen, 1994a).

As a consequence of the new research direction, the amount of publications emanating from the department increases rapidly, and 250 are presented internationally in the period 1985-1995. This trend is reinforced in the following years, and ITK soon gets a reputation for producing numerous high-quality publications.

\section{The Golden Feedback Loop}

At the 40th anniversary celebration of the Department of Engineering Cybernetics in 1994, Jens establishes a tradition that will become very popular in the coming 


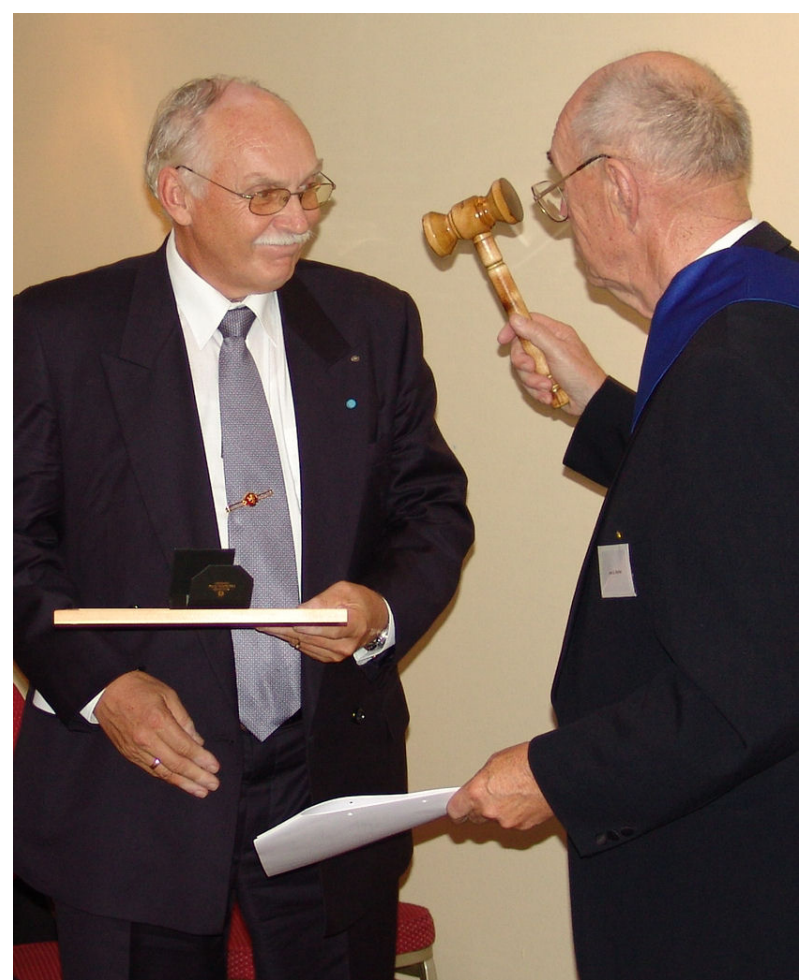

Figure 14: In 2004, Jens awards a mastership in the Order of the Golden Feedback Loop to Rolf Skår, then managing director of the Norwegian Space Centre (Norsk Romsenter). Photo: Pål Johansen.

years. He institutes the Order of the Golden Feedback Loop, with himself as its first Grand Master. All subsequent $\mathrm{PhD}$ students graduating from the department have to swear the cybernetic oath which makes them knights of this order. For example, they must promise to promote control science in all their conduct by always behaving optimally and never straying into the right half plane, which is technical jargon for being nice and never doing something bad. The oath and its accompanying ceremony always bring forth a big smile on the face of people attending the associated PhD defenses, but also serve to give a sense of solemnity to the occasion. Afterwards, the fresh $\mathrm{PhDs}$ receive a small golden pin and a diploma certifying their knighthood.

Ten years later, the department celebrates its 50th anniversary. In September 2004, a grand banquet dinner is held at the venerable Britannia Hotel in downtown Trondheim. Among the guests are prominent figures within cybernetics from both home and abroad. Following the speeches, some of the guests move down into the basement of the hotel to witness something unusual. Jens has decided to award honorary degrees to some carefully selected individuals who have "...to a special degree promoted cybernetics." Former department graduates such as Terje Mikalsen, Nils Albert Jenssen and Steinar Sælid obtain the newly created rank of Master of the Order of the Golden Feedback Loop. Other recipients include the UCSB professors Petar Kokotović and Dale Seborg. Rumor has it that the accompanying diploma is the only one found worthy by the richly distinguished Kokotović to put on his office wall.

Later that same year, at the traditional ITK "Beer and Sausage Party" ("Øl- og pølsefesten") just before Christmas in 2004, Jens hands over the role of Grand Master to Kristin Pettersen, the first female professor at the department. In 2006, she elevates him to the status of Commander of the Order of the Golden Feedback Loop, a recognition only given to those that have "...to an extraordinary degree promoted cybernetics." Needless to say, no one else has since been awarded this status.

Not only did Jens establish the Order of the Golden Feedback Loop, he also initiated regular departmental seminars under the name Cybernetic Forum. In addition, he served as Santa Claus during the ITK Christmas balls for many years. This task he carried out with great enthusiasm, as many children of the employees remember with joy. His contributions in these areas made the department not only a great place to work but also a great place to be.

\section{And then on to Lobsters}

How did Jens spend his time at the age of 76 , when he was interviewed for (Sand and Dragland, 2002)? Did he recollect the past? Did he bathe in the radiance of his achievements? Did he perhaps write his memoirs? The answer was none of the above. In the autumn of 2002, Jens worked to get a NOK 100 million project on lobster farming going.

A lobster is a strange creature and a considerable technical challenge. It flaps around on the sea bottom with an apparently amorphous body, eats whatever it finds like a sort of sanitation service of the seas, before humans catch it in lobster pots and serve it as a delicacy. Only a pity it is so costly. In the 1930s, Norwegian fishermen caught 1300 tons of lobsters a year. Today the catch is down to 50 tons.

"We want to recreate the golden age of the Norwegian lobster industry," Jens explains in 1998 when interviewed for the research magazine Gemini (Dragland, 1998). Elaborating: “Considering Norway's enormous lobster resources 200 years ago and the thousands of tons of lobster harvested in Norway just 50 years ago, we have a lot to aim for." Claiming that: "Efficient 
production is made possible through the combination of biological know-how and modern automation technology."

Since Jens grew up in the southern part of Norway he naturally appreciates a good lobster dinner. Already at an early age he started thinking about the feasibility of lobster farming. The problems were many - also beyond the cybernetic ones - but it didn't frighten him. Jens modeled the life span and discovered what was required in each particular phase, the spawn phase being the most critical one. It will not be possible to achieve farming of lobsters without access to spawn. But lobster spawn are pitiful creatures that easily fall victim to other animals. Including bigger lobsters since the lobster is a cannibal, which Jens' learns the hard way when a certain batch of cubs results in one single, giant lobster.

Jens then devises a clever construction whereby the lobster eggs are hatched in special tubs, and then isolated in separate rooms. Cameras monitor the lobsters and report about dead or deformed animals. These are replaced with healthy individuals. Feeding is performed automatically. When the cubs reach one year, they can be placed out on the seafloor. The lobster flourishes at depths from 5 to 40 meters, where it wants firm ground with rocks, mussels and crabs. Jens develops a system which maps the sea bottom before the cubs are transported out. Each cub is awarded ten square meters. They are planted like potatoes in a field. On arrival, the cubs bury themselves into the ground and disappear for two years.

The lobster is relatively stationary. It remains where it is put out. In any case, the lobster does not venture deeper than 40 meters, and if put out by an islet it stays there. Cheaper paddocks can't be found. Jens imagines lobster fishing as a harvest equivalent to strawberry picking. The harvesting system is in development. With the help of computer-controlled boats and an automatic navigation system, he foresees a harvest of a thousand lobsters per day. Today, a lobster fisher only picks up some tens of cages.

Jens Balchen's high-tech lobster world didn't just arrive floating on a slab. Back in 1981, he planned a lobster factory at Holla Smelteverk at Kyrksæterøra in companionship with Tiedemanns Tobacco Company. The facility was closed in 1994. Jens since worked with the planning of a fully automated factory with a capacity 40 times as large. However, legal issues concerning harvesting rights have prevented the commercialization of lobster farming until 2001, when the new "Law on Ocean Pasture" ("Lov om havbeite") was introduced. This law means that the ocean is no longer public property where everybody can help themselves to the precious lobster. The law opens for licenses to put out lob-

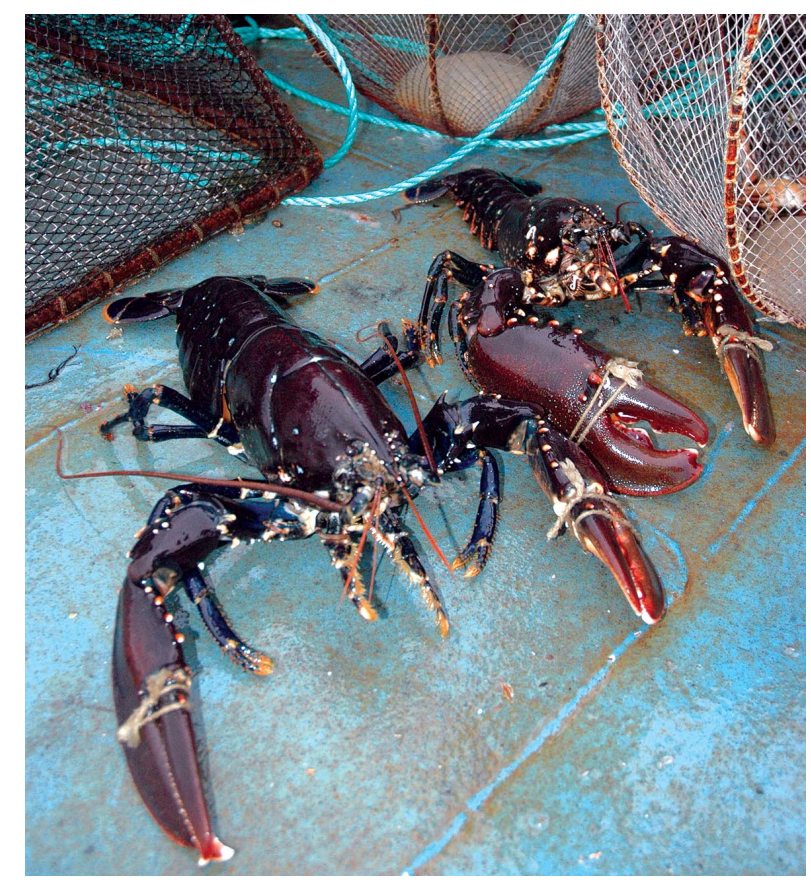

Figure 15: The cannibalistic lobster is particularly difficult to breed. Photo: Frode Jensen.

sters and sole rights to harvest them in limited areas. Still, detailed regulations are yet to be fully developed and discussions on how the law should be interpreted are still ongoing.

In 2002, Jens needed NOK 100 million, which he hoped would arrive. The facility would be built on Tjeldbergodden, courtesy of the company Norsk Hummer. He aimed to take advantage of the waste heat from one of the processing plants of the Norwegian oil and gas giant Statoil. "Lobster production is perfect for Norway. It utilizes our competency and provides work places for the districts. And of course lobster is delicious," said Jens, who rounded off with a sigh related to the fact that the lobster project had been an awfully difficult challenge at times.

In 2007, Norsk Hummer got a license for land-based production of lobster spawn on Tjeldbergodden. The facility was ready in 2008. However, lobster farming has yet to become a profitable endeavor, which is attributed to both the breeding and legal complexities. Although this project was the crown jewel in Jens' aquaculture dreams, he never lived to see its fruition.

\section{A Craze for Solving Problems}

When Jens was asked back in 2002 how it could be that his research field involved everything from ves- 
sel steering and control of industrial processes to fish, aquaculture and lobsters, he explained that he enjoyed having numerous balls in the air at the same time: "I have been terribly patient in some contexts. The bureaucracy uses too much time to decide. Then it's good to have something else to spend my energy on in the meantime."

At the same time, Jens was an impatient person. When he assigned his brain cells toward a problem, they ran nonstop: "I probably have a craze for solving problems. The brain works continuously to solve them. I sometimes solve problems in my sleep."

There exists an infinitely large amount of problems in this world that haven't been solved. But not all problems need a solution, the system still works well. "My attitude is that we should start with the problems we get a benefit from solving," Jens said. Success in research doesn't just mean that we get things to work, but just as much that someone wants the result afterwards.

The ability to think and choose differently characterized Jens throughout his life. The solutions often involved technology leaps as he applied new research results or brought new perspectives to old problems. Technology push wasn't always good Latin, but might be necessary. Jens Glad Balchen's research career was a long continuous technology push.

\section{Professor Emeritus}

In 1996, the same year as NTH merges into the Norwegian University of Science and Technology (Norges teknisk-naturvitenskapelige universitet, NTNU), Jens retires and becomes a professor emeritus. Until this moment, he has always insisted on lecturing the basic course in control engineering. Now he must leave this task to younger forces.

Jens' views on teaching are illustrated in the Aftenposten interview from 1966: "While I would argue that teachers should do research, I would also claim that researchers should teach. To be a researcher and exclusively employed to be brilliant from 9 to 16 is an almost hopeless task. You have periods when you just can't come up with anything. Then you're still not useless because you can disseminate your knowledge to those that follow. That is what is called teaching." Elaborating: "This interaction between passing on what you have learned to others and creating something new is very important. . . I I believe we must link industry researchers closer to education." Later, when explaining what cybernetics is about in (Balchen, 1997), he adds: "There are many students over the years who have had a profound experience when they through their education in control engineering understand how the behav- ior of complex systems can be described by using efficient mathematical tools."

During his career, Jens published over 150 scientific articles and numerous reports on classified projects. The articles include (Balchen, 1955) on the use of analog computers for control purposes; (Balchen, 1961) on nonlinear control systems; (Balchen and Aune, 1965) on optimal control systems; (Balchen, 1967) on industrial automation issues; (Balchen, 1969) on systems engineering education; (Balchen and Baggerud, 1970) on adaptive state estimation; (Balchen, 1972) on control of schooling fish; (Balchen et al., 1973) on multivariable PID control; (Balchen, 1975) on modeling of fish behavior; (Balchen et al., 1976) on dynamic positioning of ships; (Balchen, 1977) on modeling, identification and control of economic systems; (Balchen, 1979) on computer-aided design in control systems; (Balchen, 1980) on process control; (Balchen et al., 1981) on laboratory experiments for educational purposes; (Grimsen et al., 1986) on lobster farming; (Lunde et al., 1987) on robotic manipulators; (Balchen et al., 1988) on model predictive control; (Balchen, 1990) on offshore fish farming; (Fossen and Balchen, 1991) on autonomous underwater vehicles; (Volden and Balchen, 1993) on image processing; (Balchen and Sandrib, 1994) on control with input saturation; (Balchen, 1995) on model-based teleoperation of underwater vehicles; (Yin and Balchen, 1997) on image compression and transmission; and (Balchen, 2002) on automation in fisheries and aquaculture. In addition, Jens contributed to 8 books, and supervised a total of $61 \mathrm{PhD}$ students and an untold number of MSc students. He was also awarded numerous patents on everything from fish farming to robot manipulators.

The Department of Engineering Cybernetics is still developing. The scope of its teaching, research, staffing and budget has grown steadily. In 2009, ITK had five main target areas: Process Cybernetics, Motion Control, Fisheries and Aquaculture Cybernetics, Medical Cybernetics and Industrial Computer Systems. To handle all this activity, the department employs ten professors, four associate professors and one assistant professor. In addition, eight adjunct professors are associated with the department, most of them hailing from the industry.

Each year, ITK graduates approximately $80 \mathrm{MSc}$ students and $10 \mathrm{PhD}$ students, making it the national engine for education of cyberneticists in Norway. In total, close to $150 \mathrm{PhD}$ students have now graduated since the first degree was awarded to Arne G. Berre for his thesis on Automatic Control of Batch Processes in 1961, ensuring that Jens' influence and significance for Norwegian industry and commerce will continue long after his own departure. 


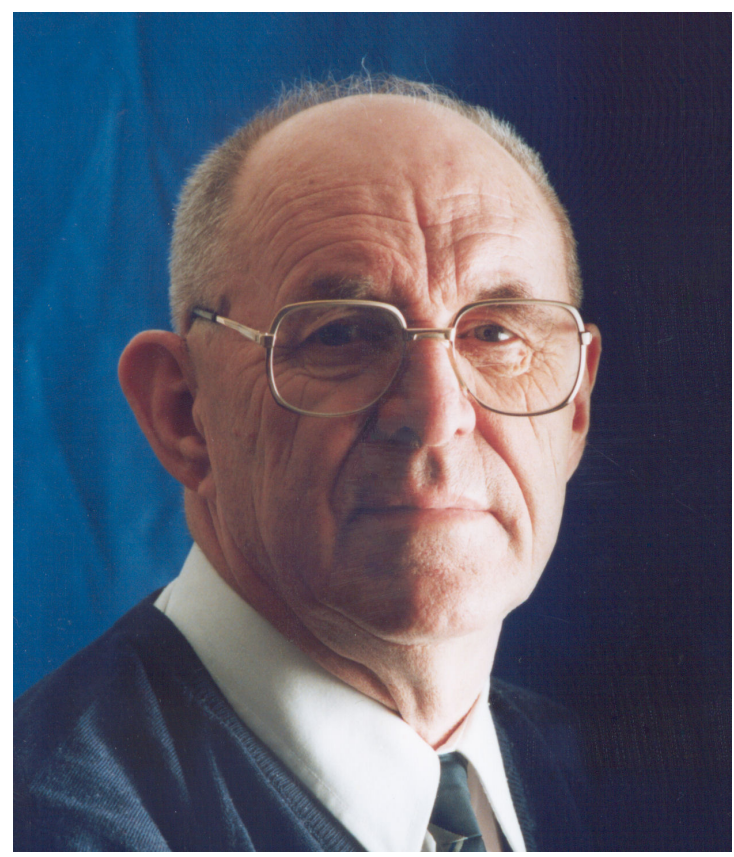

Figure 16: Jens Glad Balchen photographed in 1997 on the occasion of his article summarizing over 40 years of efforts in engineering cybernetics at NTH (Balchen, 1997). Photo: Gøril Klemetsen.

Not that he had plans to depart anywhere. Right up until the end, he still used his privileges as a professor emeritus and arrived punctually in his not-too spacious office every morning. Here, in his own cave, surrounded by large amounts of books, ring binders and filing cabinets, he pondered continuously on new cybernetic applications. His hair had become thinner since Aftenposten took their picture in 1966, but the eyes were the same - clear, sharp and kind.

A true cyberneticist at heart, Jens Glad Balchen explored theory and applications within numerous different fields. He early recognized the potential of computers for control purposes and advocated the use of model-based control methods throughout his career. Jens had an invaluable influence on key technological industries in postwar Norway and few Norwegian researchers have helped create more industrial companies than him. According to Jo Arve Alfredsen, associate professor in Fisheries and Aquaculture Cybernetics at ITK, Balchen “...was revolutionary, he turned things upside down, in contrast to others who were evolutionary." His legacy now lives on through the department he founded and the people he educated, people who currently hold key positions in important industrial companies all over Norway. Also one of the most accomplished and well-reputed departments at NTNU, ITK carries on Balchen's vision of how cybernetics should be taught, explored and applied.

\section{Awards Aplenty}

Marks of recognition and respect haven't been lacking. In 1984, Jens received the IEEE Centennial Medal through which he was "...honored for extraordinary achievement ... deserving of special recognition" by the largest professional organization in the world concerned with the advancement of technology ${ }^{4}$. In 1987, the Université de Liége in Belgium awarded Jens an honorary doctorate. He was given the NTNF's honorary price in 1990, and received the honorary price from the Norwegian Society of Automatic Control in 1991.

Balchen was appointed Commander of the Order of St. Olav by the King for his service for Norwegian technology research in 1996, and got the Rosing Honorary Award from the Norwegian Computer Society (Den Norske Dataforening) in 2000. Also in 2000, Jens received the Nordic Process Control Award, which is given "...to persons who have made a lasting and significant contribution to the field of process control." In 2004, he was awarded an honorary membership from the Society of Norwegian Ocean Researchers (Norske Havforskeres Forening), and was in 2006 given the

\footnotetext{
${ }^{4}$ The Institute of Electrical and Electronics Engineers (IEEE) is an international non-profit professional organization for the advancement of innovation and technological excellence with more than 375000 members in more than 160 countries.
} 
Gunnerus Medal from the Royal Norwegian Society of Sciences and Letters (Det Kongelige Norske Videnskabers Selskab, DKNVS) for “...extensive pioneering research of high international standard in engineering cybernetics and its possible applications in our society."

The IEEE elevated Jens to Fellow in 1995, an honor bestowed only upon a very select few and conferred "... upon a person with an extraordinary record of accomplishments in any of the IEEE fields of interest." He later received the status of IEEE Life Fellow in 2004. Then, in 2006 he was appointed a Fellow of IFAC when attending the 50th anniversary celebration of the organization in Heidelberg, Germany. Jens received the fellowship for "... outstanding contributions to control engineering research and education in Norway and to the theory and practice of control engineering, as well as for services to IFAC in the early years of the Federation."

For a couple of decades, Jens also participated at the annual meetings of the American Institute of Chemical Engineers (AIChE). He always brought his wife Inger, and these meetings became their yearly trip to the US. In addition to the usual awards given at such meetings, an irony award was also handed out. Dale Seborg from UCSB, a very good friend of Jens, was notoriously known for always being late with reviews, project applications, etc. Once he got the AIChE irony award for this behavior, and a proposal was made for his epitaph: "RIP. He even was too late for his own funeral." It was unclear whether Jens had anything to do with this suggestion, but once he proposed giving the price to Manfred Morari of ETH Zurich for rediscovering the Kalman filter. Surely enough, Morari received the price for exactly this reason. But with the eagerness shown by Jens in these matters, he naturally had to receive the irony award himself some time. Or to be exact, it was his wife Inger who received the award: "For putting up with him through all these years."

\section{Family Matters}

There is a saying that behind every great man there is a great woman. Jens' great woman was his wife Inger.

Inger met Jens during the spring of 1955. She is then 23 and he will soon turn 29. Both on a cabin trip with friends, Inger acts as a chaperone for a girlfriend, while Jens comes along with one of his comrades. Inger is a beautiful young woman with high spirits and lots of temper, something the ambitious young professor can't resist. Nobody can reprimand Jens as Inger can.

Two weeks after their first meeting they get engaged. The wedding takes place early the following year. On Saturday February 4th 1956, Jens and Inger tie the knot. Their first child Jens Jr. is born in December

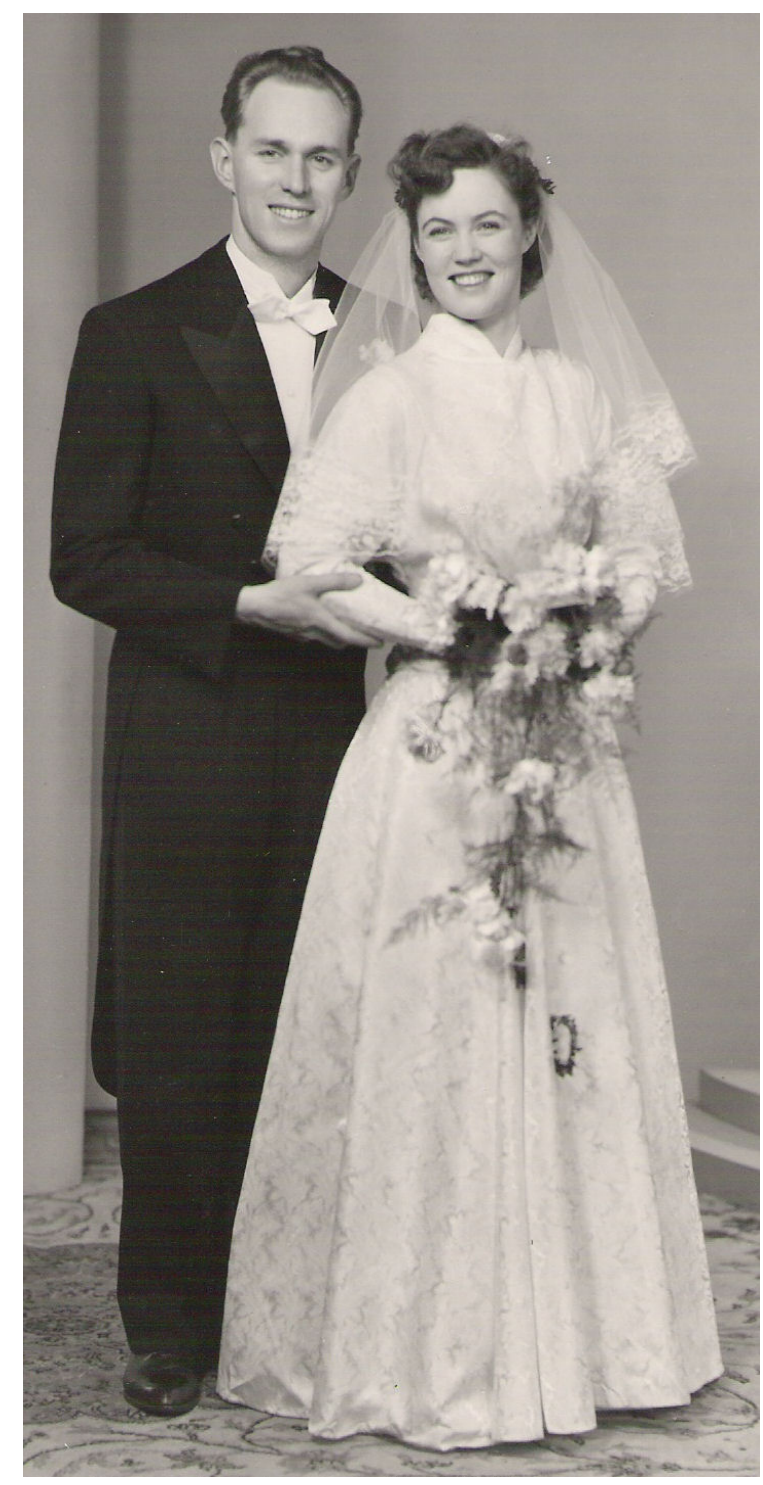

Figure 17: A happily married young couple in 1956.

1956. A house is built a stone's throw from NTH and Inger becomes a fulltime housewife and mother. When Siri arrives in 1961 the family is complete.

Inger and Jens love the outdoors and build a cabin in the mountains. The cabin becomes an important place for the family to gather. In time, they also take possession of a cabin in Southern Norway inherited from Jens' parents. Here, they will spend many happy summers in the years to come. Cabin life lays a foundation for many new ideas that are later adopted for various well-known projects, in particular control of fish and lobster farming.

It isn't always easy for Inger to be the wife of a successful professor. Jens travels a lot and loves to be 
in creative and hectic environments, while Inger looks after their home and children. When Jens receives the honorary price from NTNF in 1990, Inger is also solemnly praised for her effort as "Jens' wife" - without her much would have been different. She organizes receptions and gatherings, and also associates with many 'colleagues' in the "Professor Wives Club", which becomes a social meeting place for professors and their spouses. Inger shows great care for foreign students at ITK and regularly hosts home visits and cabin trips.

Inger and Jens also travel much together. They live in the United States at several occasions and obtain a large and prominent circle of friends there.

The years 1977 to 1988 witness the arrival of 3 grandchildren. Jens, Janneke and Lasse receive great attention and care from their grandparents.

Inger passes away peacefully 5 months after Jens.

\section{Concluding Remarks}

Many characterized Jens as an inspiring human being. He glowed for what he believed in and inspired others to do the same. At the same time he had a temper. Sometimes it could blow quite freshly in the neighborhood. Jens knew how to let his environment know when the world worked against him. Colleagues and others that were in his vicinity described him as difficult to handle at times. Which Jens protested: "Difficult? Me? Absolutely not! I am like a lamb. A soft man!"

But Balchen's quarrelsome nature was undoubtedly also a success factor. The temper reflected an intense energy, which is a necessary part of the creative process. Jens was known to never give up. He walked through concrete to get what he wanted. To this he agreed: "I don't take no for an answer. Many who disagree with me in the beginning change their opinion once I get the chance to explain to them how foolish they were thinking in the first place."

According to Steinar Sælid, one of the researchers working with Balchen on the development of the ground-breaking DP systems of the 70 s and $80 \mathrm{~s}$, and now himself a successful businessman through his company Prediktor, Jens “. . had an amazing flair for technology. What is possible? In which direction should a solution be sought out? What can we use this for? That was Jens' real strength. Not the subtle proofs and theories, but an impressive synthetic talent to find solutions and product ideas, as well as a tremendous entrepreneurial drive and ability to persuade and initiate." Adding: "For me personally, Jens has meant an enormous amount. In addition to being a tremendously inspiring teacher and mentor, he taught me and many others that nothing was too difficult to analyze or achieve. And he taught me that the most interesting problems in control theory and engineering science were the ones related to a problem whose solution is of practical use. It is not so interesting to prove something which everyone already knows is working. And he taught many of us the joy of daring to gamble, to take chances, to build something, even though many believed it would never work!"

The evening before Jens' funeral, the Chancellor of NTNU stated: "Tomorrow NTNU flags in honor of an outstanding personality for NTNU and for Norway."

\section{Epilogue}

We would like to end this article with some personal accounts:

Morten Breivik: I began studying engineering cybernetics at NTNU in 1998, two years after Jens retired, and thus never experienced his teaching abilities first hand. Still, my father, who studied mechanical engineering at NTH in the early 1970s, has told me that he had him as a teacher in a basic control engineering course.

However, I've attended several presentations Jens has given, and especially remember a funny story he once told about how and why women synchronize their menstrual periods when living together for a long period of time, and what potentially disastrous effects this phenomenon can have. I also vividly remember the story of how, when starting to experiment with lobster farming, they ended up with one giant lobster after having originally put out a large number of cubs.

During my MSc study, I also recall that there for some reason was a huge freezer located in the same laboratory as where we performed instrumentation and magnetic-levitation experiments. This freezer contained large amounts of seafood, and we used to joke about how this content was related to Jens' lobster projects.

Later, I have gradually learned more of Jens' adventures through my MSc and PhD studies. Since I have always been very fascinated by and interested in technology history, I jumped at the chance of participating to write an article about him for MIC's 30th anniversary issue. Most of what has been written about Jens is in Norwegian only, so I definitely think it's about time his contributions are introduced to a larger audience. His accomplishments certainly inspire my own work and I believe many useful lessons can be learned for anyone involved in research.

I treasure the opportunity to get better acquainted with the history and origin of engineering cybernetics in Norway, a discipline that has been vastly enriched by the colorful contributions of Jens Glad Balchen. 
Gunnar Sand: I was acquainted with Jens in 1988. I had just started working with SINTEF and was attending my first management meeting. Jens entered the room with a pile of documents in his hands, found a seat next to mine, looked me up and down and said: "Who are you and what are you doing here?" I told him the basic facts. He shook his head and exclaimed: "You're not even an engineer?"

We got on well. My background in mathematics and philosophy was not his cup of tea - to put it mildly but we got on well. I remember quite a few occasions when he would drop by my office after management sessions at SINTEF to share his frustration about incompetent colleagues. "They don't even have doctoral degrees," he would say, before realizing that neither did I. Then he got up, said "Oh well," and left, shaking his head in disbelief.

When I was assigned to contribute to a book about outstanding scientists in 2002, Jens was an obvious choice. We hired co-authors to do many of the interviews, but I did the Balchen profile myself. I remember the initial contact well: He demanded full control over the final result. I told him that would not be the case. Then he flashed a smile and said that at least I should not moderate his expressions. As I had no intention to do so, I agreed.

When I got the news that Jens was dead, the world stopped spinning for a while. I remembered the last time we met, in his office. He was close to 80 years old, and I asked him what he was doing in his office at this age. His answer was: "Where should I be if not in my office? Norway has no need for people doing nothing!"

Jens Glad Balchen never stopped reminding me that I was an uneducated bureaucrat that did not deserve his time. But we got on well. And it's a shame he's not around anymore.

\section{Acknowledgments}

This work was supported by the Norwegian Research Council through the Centre for Ships and Ocean Structures. The authors would especially like to thank the following people for helping out with invaluable information and material: Jo Arve Alfredsen, Bjørn Angelsen, Arne Asphjell, Jens Glad Balchen (the son of our cybernetics pioneer), Magne Fjeld, Rolf Henriksen, Bård Holand, Nils Albert Jenssen, Tor Arne Johansen, Stig Kvaal, Kristin Ytterstad Pettersen, Odd Pettersen, Dag Slagstad, Einar Svendsen, Steinar Sælid and Bjørnar Vik.

\section{References}

Aadland, C. Ingeniørbragden! Teknisk Ukeblad, 2009. URL http://www.tu.no/industri/ article230776.ece.

Asphjell, A. Jens G. Balchen: Reguleringsteknikkens grand old man. Universitetsavisa, 2004. URL http://www. universitetsavisa.no/ua_lesmer. php?kategor $i=n y h e t e r \& d o k i d=4148 c 581 \mathrm{e} 1 \mathrm{e} 8 \mathrm{~b} 2$. 47453348.

Asphjell, A. and Børresen, A. K. Institutt for teknisk kybernetikk 50 år. ITK, NTNU, Trondheim, 2004.

Balchen, J. G. Analog computers in control engineering (in Norwegian). Teknisk Ukeblad, 1955. 102(23):498502 .

Balchen, J. G. Stability of Nonlinear Feedback Systems Using the Liapunov 2. Method. Norwegian Institute of Technology, Trondheim, 1961.

Balchen, J. G. New possibilities in industrial automation (in Norwegian). Teknisk Ukeblad, 1967. 114(39):704-708.

Balchen, J. G. Systems engineering in engineering education. In Proceedings of the EUSEC/FEANI Education Conference, Oslo, Norway. 1969.

Balchen, J. G. Feedback control of schooling fish. In Proceedings of the 5th IFAC World Congress, Paris, France. 1972.

Balchen, J. G. Mathematical modelling of fish behaviour: Principles and applications. In Proceedings of the 6th IFAC World Congress, Boston, Massachusetts, USA. 1975.

Balchen, J. G. Political aspects of modelling, identification and control of economic systems: A survey of rationales and goals. In Proceedings of the Workshop on Mathematical Modelling, Identification and Control of Sectoral and National Economies, Trondheim, Norway. 1977.

Balchen, J. G. The need for computer-aided design in modelling and control of non-technical systems. In Proceedings of the IFAC Symposium on ComputerAided Design of Control Systems, Zurich, Switzerland. 1979.

Balchen, J. G. Dynamic optimization in the process industry. In Proceedings of the 5th International Congress in Scandinavia on Chemical Engineering, Copenhagen, Denmark. 1980. 
Balchen, J. G. The state of the art in offshore fish farming. In Proceedings of the Conference on Engineering for Offshore Fish Farming, Glasgow, Scotland. 1990.

Balchen, J. G. Model based teleoperation of untethered underwater vehicles with manipulators, MOBATEL. In Proceedings of the 3rd IFAC Workshop on Control Applications in Marine Systems, Trondheim, Norway. 1995.

Balchen, J. G. Teknisk kybernetikk - et fagområde i sterk vekst. In M. Hård, A. Kjærvik, S. Kvaal, P. K. Larsen, O. Lauritzen, and E. Rødahl, editors, Teknologi for samfunnet: NTH $i$ en brytningstid 1985-1995, pages 140-151. NTNU, Trondheim, 1997. URL http://www.ntnu.no/info/ nthbok/140-151balchen.html.

Balchen, J. G. Thirty years of research on the application of cybernetic methods in fisheries and aquaculture technology. Modeling, Identification and Control, 2000. 21(1):3-64. doi:10.4173/mic.2000.1.1.

Balchen, J. G. Automation in fisheries and aquaculture technology. In H. Unbehauen, editor, Encyclopedia of Life Support Systems (EOLSS), chapter Control Systems, Robotics and Automation, page 6.43.35.5. Eolss Publishers, Oxford, UK, 2002. URL http: //www. eolss.net.

Balchen, J. G. and Aune, A. Semidynamic optimal control. In Proceedings of the 2nd IFAC Symposium on the Theory of Self-Adaptive Control Systems, Teddington, UK. 1965.

Balchen, J. G. and Baggerud, A. An adaptive state estimator. In Proceedings of the 2nd IFAC Symposium on State and Parameter Estimation, Prague, Czechoslovakia. 1970 .

Balchen, J. G., Endresen, T., Fjeld, M., and Olsen, T. O. Multivariable PID estimation and control in systems with biased disturbances. Automatica, 1973. 9(3):295-307. doi:10.1016/0005-1098(73)90054-X.

Balchen, J. G., Håndlykken, M., and Tyssø, A. The need for better laboratory experiments in control engineering education. In Proceedings of the 8th IFAC World Congress, Kyoto, Japan. 1981.

Balchen, J. G., Jenssen, N. A., Mathisen, E., and Sælid, S. A dynamic positioning system based on Kalman filtering and optimal control. Modeling, Identification and Control, 1980. 1(3):135-163. doi:10.4173/mic.1980.3.1.
Balchen, J. G., Jenssen, N. A., and Sælid, S. Dynamic positioning using Kalman filtering and optimal control theory. In Proceedings of the IFAC/IFIP Symposium on Automation in Offshore Oilfield Operations, Bergen, Norway. 1976.

Balchen, J. G., Ljungquist, D., and Strand, S. State space model predictive control of a multi-stage electro-metallurgical process. In Proceedings of the IFAC Workshop on Model Based Process Control, Atlanta, Georgia, USA. 1988.

Balchen, J. G. and Sandrib, B. Input saturation in nonlinear multivariable processes resolved by nonlinear decoupling. In Proceedings of the 3rd IEEE Conference on Control Applications, Glasgow, Scotland. 1994.

Bjerva, K. G., editor. Norcontrol: Maritim innovasjon siden 1965. Norcontrol/Kongsberg Maritime Pensjonistforening, Horten, 2006.

Bjørnstad, S. Shipshaped: Kongsberg Industry and Innovations in Deepwater Technology, 1975 - $200 \%$. Ph.D. thesis, BI Norwegian School of Management, Oslo, Norway, 2009.

Bray, D. Dynamic Positioning. Oilfield Publications Inc., 2003.

Brown, G. S. and Campbell, D. P. Principles of Servomechanisms. John Wiley and Sons, Inc., New York, 1948.

Buland, T. Det norske forskningsregimet 1945-1990. STS Working Paper 3/95, Centre for Technology and Society, University of Trondheim, 1995.

Conway, F. and Siegelman, J. Dark Hero of the Information Age: In Search of Norbert Wiener - The Father of Cybernetics. Basic Books, New York, 2005.

Dragland, A. "Baby-boom" på Tjeldbergodden. Gemini, 1998. 11(3). URL http://www.ntnu.no/ gemini/1998-03/27.html.

Faÿ, H. Dynamic Positioning Systems: Principles, Design and Applications. Éditions Technip, Paris, 1990.

Fossen, T. I. and Balchen, J. G. The NEROV autonomous underwater vehicle. In Proceedings of the IEEE OCEANS'91, Honolulu, Hawaii, USA. 1991.

Grimsen, S., Jaques, R. N., Erenst, V., and Balchen, J. G. Aspects of automation in a lobster farming plant. In Proceedings of the IFAC Symposium on Automation and Data Processing in Aquaculture, Trondheim, Norway. 1986. 
Gulowsen, J. Bro mellom vitenskap og teknologi: SINTEF 1950-2000. Tapir Akademisk Forlag, Trondheim, 2000.

Høivold, I. Norwegian research and development in the field of ship automation. Modeling, Identification and Control, 1984. 5(3):171-178. doi:10.4173/mic.1984.3.4.

Høivold, I. Uten nisselue: Historien om Norcontrol, 2003. Unpublished personal memoirs.

Kittilsen, F. Institutt for teknisk kybernetikk: Stamfar til norske bedrifter i verdensklasse. Bladet Forskning, 1994a. 2(7). URL http://forskningsradet.ravn.no/bibliotek/ forskning/199407/1994070801.html.

Kittilsen, F. Simrad Albatross: En stødig lausunge fra Kongsberg. Bladet Forskning, 1994b. 2(7). URL http://forskningsradet.ravn.no/ bibliotek/forskning/199407/1994070701.html.

Kvaal, S. Drømmen om det moderne Norge. Automasjon som visjon og virkelighet i etterkrigstiden. STS Report 13, Centre for Technology and Society, University of Trondheim, 1991.

Kvaal, S. NTNFs servotekniske utvalg: Utvalget for de moderne ting. STS Working Paper 4/92, Centre for Technology and Society, University of Trondheim, 1992.

Kvaal, S. Hooked on a new technology: The automation pioneers in post-war Norway. Modeling, Identification and Control, 2009. 30(3):87-100. doi:10.4173/mic.2009.3.1.

Lunde, E., Egeland, O., and Balchen, J. G. Dynamic control of kinematically redundant robotics manipulators. Modeling, Identification and Control, 1987. 8(3):159-174. doi:10.4173/mic.1987.3.4.

Nordal, O. Tool or science? The history of computing at the Norwegian University of Science and Technology. In J. Impagliazzo, T. Järvi, and P. Paju, editors, History of Nordic Computing 2, pages 121-129. Springer, 2009.

Overbye, S. Fra forskning til industri: Utviklingen av skipsautomatiseringsbedriften Norcontrol. Master's thesis, University of Oslo, 1989.

Ryvik, H. Stødig på alle hav. Teknisk Ukeblad, 1999. URL http://web.tu.no/nyheter/arkiv/ ?id=1999/33/s2425/s2425.html.

Ryvik, H., editor. Norsk Forening for Automatisering: Automatisering for å bygge Norge. NFA, Kristiansand, 2008.
Sand, G. and Dragland, A. Professoren som ble industribygger. In G. Sand and K. Skretting, editors, Fortellinger om forskning, pages 48-61. Tapir Akademisk Forlag, Trondheim, 2002.

Sælid, S., Jenssen, N. A., and Balchen, J. G. Design and analysis of a dynamic positioning system based on Kalman filtering and optimal control. IEEE Transactions on Automatic Control, 1983. 28(3):331-339. doi:10.1109/TAC.1983.1103225.

Volden, R. and Balchen, J. G. Determining 3-D object coordinates from a sequence of $2-\mathrm{D}$ images in modeling ROV environments. In Proceedings of the 8th International Symposium on Unmanned Untethered Submersible Technology, Durham, New Hampshire, USA. 1993.

Wicken, O., editor. Elektronikkentreprenørene. AdNotam Gyldendal, 1994.

Wiener, N. Cybernetics: or Control and Communication in the Animal and the Machine. MIT Press, Cambridge, 1948.

Yin, S. and Balchen, J. G. Image compression and transmission through a low-rate ultrasonic link in subsea telerobotic applications. Journal of Mathematical Imaging and Vision, 1997. 7(1):41-53. doi:10.1023/A:1008214007262.

Østby, P. Tilfellet Comtec. STS Report 8, Centre for Technology and Society, University of Trondheim, 1989.

Østby, P. Creating a network: Advanced technology or primitive needs? STS Working Paper 6/90, Centre for Technology and Society, University of Trondheim, 1990.

Østby, P. En automatisk fabrikk? Bedriftsetablering i skjæringspunktet mellom vitenskap og industri. STS Working Paper 5/91, Centre for Technology and Society, University of Trondheim, 1991. 